\title{
Ю.І. Фещенко
}

\section{СУЧАСНІ ТЕНДЕНЦІЇ ВИВЧЕННЯ ПРОБЛЕМ ТУБЕРКУЛЬОЗУ}

\section{СУЧАСНІ ТЕНДЕНЦІЇ ВИВЧЕННЯ ПРОБЛЕМ ТУБЕРКУЛЬОЗУ \\ Ю. І. Фещенко \\ Резюме}

ДУ «Національний інститут фтизіатрії і пульмонології ім. Ф. Г. Яновського НАМН України»

в 1993 году ВОЗ впервые в своей истории признала туберкулез глобальной опасностью и сообщила, что если правительства стран не будут считать борьбу с туберкулезом своим первым приоритетом и финансировать борьбу с этим заболеванием, то туберкулез нанесет колоссальный ущерб экономикам и населению нашей планеты.

До 2006 года Украина не могла справиться с эпидемией туберкулеза, поскольку с 1990 до 2000 года не выделялись целевые средства на закупку антимикобактериальных препаратов, больные лечились хаотично за свой счет. Так, в период с 1990 по 2005 годы заболеваемость всеми формами туберкулеза увеличилась в 2,64 раза (с 31,8 до 84,1 на 100 тыс. населения), смертность от туберкулеза увеличилась в 2,88 раз (с 8,8 до 25,3 на 100 тыс. населения). Это привело к существенному росту химиорезистентности. Худшая ситуация по туберкулезу в юго-восточном регионе Украины и в учреждениях пенитенциарной системы. За последние несколько лет убытки от туберкулеза в Украине составляют около 3,5 млрд грн в год.

В представленной фундаментальной статье изложены сведения об эпидемиологии и патогенезе туберкулеза, причинах неудовлетворительной эпидемиологической ситуации в Украине, дана подробная характеристика методов диагностики, в том числе молекулярно-генетических, детально представлены принципы и режимы химиотерапии туберкулеза, основные направления его профилактики, а также прогноз развития эпидемической ситуации в мире и Украине.

Ключевые слова: туберкулез, эпидемиология, биология микобактерии, патогенез, диагностика, лечение, профилактика.

Укр. пульмонол. журнал. 2019, № 1, С. 8-24.

Фещенко Юрій Іванович

Директор ДУ "Національний інститут

фтиизіатрії і пульмонології

ім. Ф. Г. Яновського Начіональної академії

медичних наук України»

Академік НАМН України, профресор

10, вул. М. Амосова, 03680, Київ,

Тел.380 44 275-04-02, факс: 38044 275-21-18, admin@ifp.kiev.ua

\section{UP-TO-DATE TENDENCIES IN TUBERCULOSIS RESEARCH \\ Y. I. Feshchenko \\ Abstract}

In 1993 WHO has first in its history accepted tuberculosis as a global threat. It declared that if world governments would not consider tuberculosis fight their firs priority and provide proper funding, tuberculosis would cause a colossal harm to economics and population of the planet.

Until 2006 Ukraine could not take under control the epidemic of tuberculosis because of insufficient financial spending during 1990-2005 years for target purchase of antimycobacterial drugs. The patients received treatment irregularly, buying medicines at their own expense. Thus, during the period from 1990 till 2005 the morbidity of tuberculosis (all forms) increased by 2,64 times (from 31.8 to 84.1 per 100000 population), mortality - by 2.88 times (from 8,8 to 25.3 per 100000 population).This led to significant growth of chemoresistance. The worth situation was registered in South-East region of Ukraine and at penitentiary system institutions. For the last years the losses due to tuberculosis have reached 3.5 billions per year.

This fundamental article presents the epidemiology and pathogenesis of tuberculosis, the causes of unsatisfactory epidemic situation in Ukraine. A detailed characteristics of diagnostic methods, including molecularbiology tests, the methods of tuberculosis treatment and chemotherapy regimens, major prophylaxis approaches, and the prognosis for tuberculosis spread in the world and Ukraine are highlighted.

Key words: tuberculosis, epidemiology, biology of mycobacterium, pathogenesis, treatment, prophylaxis.

Ukr. Pulmonol. J. 2019;1:8-24.

\section{Yurii I. Feshchenko}

Director of National Institute of phthisiology

and pulmonology named after F. G. Yanovskii

National Academy of medical sciences of Ukraine

Academician of NAMS of Ukraine, professor

03680, Kyiv, 10, M. Amosova str.

Tel.: 38044275 0402, fax: 38044275 2118, admin@ifp.kiev.ua

\section{Історичні аспекти про туберкульоз}

Туберкульоз відомий людству ще з доісторичних часів. Він був повальною хворобою з найглибшої давнини. У стародавніх літописах згадується про туберкульоз як про невиліковну хворобу, "сухоти", "злі сухоти", "хвороба сухотна", "скорбота сухотна","легенева чахотка", "фтиза", а у зв'язку із позалегеневими ураженнями - "горбова хвороба", "неміч у вертлюзі", себто у кульшовому суглобі, "волосатик" (норицеві форми туберкульозу кісток і суглобів).

Про туберкульоз є згадка і у Старому Завіті Біблії. У п'ятій книзі Мойсеєвій “Второзаконня" (розділ 28, вірш 22) написано: “Вразить тебе Господь чахлістю, гарячкою, лихоманкою, запаленням, засухою, палючим вітром та іржею, і вони будуть переслідувати тебе, доки не загинеш". Всі тлумачі Біблії під "чахлістю" розуміють туберкульоз.

За археологічними знахідками останніх часів, первісна людина виникла близько 4 мільйонів років тому. Туберкульозні

(c) Фещенко Ю. І., 2019

www.search.crossref.org

DOI: 10.312.15/2306-4927-2019-103-1-8-24 ураження хребта виявлені вченими при дослідженні останків людини періоду неоліту (близько 5000 років до нашої ери). Їх знаходили у єгипетських муміях (близько 2700 років до нашої ери), у мумії молодого жреця у Фівах (близько 1000 років до нашої ери).

Численні історичні матеріали та документи свідчать про поширення туберкульозу у сиву давнину по всій нашій планеті. У давньому Китаї свідчення про туберкульоз відносяться до 4000 року до нашої ери, в Індії - до 3000 року до нашої ери.

Вже тоді знали, що сухоти заразні. В Індії, Вавилоні та серед інших племен і народностей існували закони, які вимагали ізоляції таких хворих, забороняли брати шлюб з хворими на сухоти, а чоловік мав право на розлучення з жінкою, яка захворіла. Такі закони зберігалися і в середньовічні часи нашої ери.

Найдревніша знахідка про туберкульоз на території Європи належить Бартельсу (Bartels). У 1904 р. поблизу Гейдельберга він знайшов кістяк людини, що жила в кам'яному віці (приблизно за 5000 років до нашої ери). І в цьому кістяку він виявив туберкульозне ураження декількох грудних хребців з утворенням горба.

Що характерно?! 
У однієї з єгипетських мумій (а це близько 2700 років до нашої ери) знайшли туберкульозне ураження хребта. Коли цей сухий кістковий детрит посіяли на живильне середовище, то виросли мікобактерії туберкульозу, які нічим не відрізнялися від нинішньої популяції мікобактерій. Ними заразили морських свинок, які невдовзі захворіли на туберкульоз.

Це свідчить наскільки стійкі мікобактерії туберкульозу у зовнішньому середовищі та як довго вони зберігають свою вірулентність.

У всі віки туберкульоз косив людей, заганяючи їх у могили передчасно. Хоч це була доантибактеріальна ера, але найбільші спалахи епідемій туберкульозу відбувалися з певною природною циклічністю - 24-48 років, за різними даними.

У до антибактеріальну еру близько 50,0 \% хворих на туберкульоз помирали, майже у 25,0 \% розвивався хронічний туберкульоз і смерть наступала пізніше й лише у 25,0 \% хворих наступало самовилікування і вилікування за допомогою посиленого харчування, кліматичних і санаторних факторів.

Надзвичайно велика епідемія туберкульозу з високим рівнем летальності була у Європі у другій половині XIX століття. Надзвичайно висока смертність під час цієї епідемії стала поштовхом до низки нових наукових відкриттів. Найвагомішими 3 яких були:

- 24 березня 1882 року німецький мікробіолог Генріх Герман Роберт Кох (1843-1910) відкрив збудника туберкульозу, а в 1890 році він виділив туберкулін, який виробляють мікобактерії туберкульозу під час свого росту;

- у 1895 році німецький фізик Вільгельм Конрад Рентген (1845-1923) відкрив Х-промені, які стали називатися рентгенівські промені. Ще 14 років до Рентгена український вчений Іван Павлович Пулюй (1845-1918), працюючи разом з Рентгеном у Страсбурзі, сконструював лампу Пулюя, яка виділяла ці промені;

• у 1919 році французький мікробіолог А. Кальмет і ветеринарний лікар К. Герен створили вакцинний штам мікобактерії туберкульозу для протитуберкульозної вакцинації людей. Вперше вакцина БЦЖ була введена новонародженій дитині у 1921 році. У 1925 році Кальмет передав професорові Л.А.Тарасевичу штам вакцини БЦЖ і з 1928 році в СРСР почали вакцинувати немовлят з вогнищ туберкульозної інфекції, а 3 1935 року вакцинацію стали проводити в ширших масштабах, а 3 середини 1950-х років вакцинація немовлят стала обов'язковою в СРСР;

- у 1943 році Зельман (Соломон) Ваксман (02.07.1888 16.08.1973) уродженець містечка Нова Прилука, що неподалік від Бердичева, зі своїм учнем А. Шацом виділили з грибка перший антимікобактеріальний препарат - стрептоміцин. На той час вже був відомий пеніцилін і у лабораторії Ваксмана у 1943 році з'явилися перші спостереження резистентності бактерій до пеніциліну;

- у 1946 році була доведена специфічна дія на мікобактерії туберкульозу ПАСК-натрієвої солі парааміносаліцилової кислоти (Lehman, 1946). У цьому ж році В. А. Шорін, а потім Fox, Г. Н. Першин, М. Н. Щукіна й інші встановили хіміотерапевтичну активність ізонікотинової кислоти. Це послужило основою для створення цілого ряду препаратів, похідних гідразиду ізонікотинової кислоти (ГІНК): фтивазид, тубазид, метазид, ларусан та інших.

• 31954 року у клініках туберкульозу почали застосовувати парааміносалицилову кислоту (ПАСК), тібон, препарати ізоніко- тинової кислоти (ізоніазид, фтивазид, салюзид, метазид).

• у 1954 році був розроблений піразинамід, у 1955 році циклосерин, у 1962 році - етамбутол. Рифампіцин був синтезований Maggi із співавт. в 1965 році. На початку 1970-х років XX століття почалося широке застосування цих антимікобактеріальних препаратів.

Слід зазначити, що окрім людини на туберкульоз хворіють більше 55 видів сільськогосподарських тварин, птахів і риб. Немає такого органу у людини чи тварини, який би не міг уражатися туберкульозом, хоча близько у 90,0 \% випадків уражаються легені.

\section{Дефініція}

Туберкульоз - це інфекційне захворювання, що передається від хворої людини повітряно-крапельним та іншими шляхами, викликається мікобактеріями туберкульозу (людського, бичачого і африканського штамів; а інші штами мікобактерій спричиняють мікобактеріози), і характеризується утворенням специфічних гранульом в різних органах і тканинах (специфічне туберкульозне запалення) у поєднанні з неспецифічними реакціями та поліморфною клінічною картиною, що залежить від форми, стадії, локалізації та поширеності патологічного процесу; перебігає з періодичними загостреннями, рецидивами та ремісіями, частіше вражає найбідніші, соціально дезадаптовані групи населення (біженці, мігранти, особи, які перебувають в установах кримінально-виконавчої системи, особи без постійного місця проживання, алкоголіки, наркомани тощо), спричиняє високу тимчасову та стійку втрату працездатності, вимагає тривалого комплексного лікування та реабілітації хворих, а також приводить до негативних соціально-економічних наслідків і при недотриманні стандартів щодо виявлення та лікування - до передчасної смерті, через що відноситься до соціально небезпечних захворювань.

Туберкульоз легень діагностують тоді, коли туберкульозний процес локалізований у паренхімі легені. Всі інші локалізації специфічного ураження, в тому числі внутрішньогрудних лімфатичних вузлів та ексудативний плеврит без патологічних змін в легенях, відносяться до позалегеневого туберкульозу.

При поєднанні легеневого і позалегеневого туберкульозу випадок захворювання реєструють як туберкульоз легень.

\section{Статистика туберкульозу в світі та в Україні}

На початку 90-х років XX століття в багатьох країнах світу, особливо у бідних країнах, спостерігалося непередбачуване погіршення епідемічної ситуації. Цьому найбільше сприяли:

- соціально-економічна криза, зубожіння населення, незбалансоване харчування і ослаблений колективний імунітет, стреси, особливо у країнах постсоціалістичного табору, які почали перехід до капіталізації;

- ріст хіміорезистентності й ВІЛ-інфекції;

- міграція, в т. ч. хворих на туберкульоз та багато інших причин.

Через те у 1993 році ВООЗ вперше в своїй історії забила тривогу і визнала туберкульоз - глобальною небезпекою та повідомила, що якщо уряди країн не вважатимуть боротьбу з туберкульозом своїм найпершим пріоритетом і не будуть фінансувати боротьбу з цим захворюванням, то туберкульоз нанесе колосальних збитків економікам і населенню нашої планети. 
Високорозвинені країни виділили значні кошти на подолання епідемії туберкульозу і вже через 1-3 роки взяли під контроль ситуацію з туберкульозу в своїх країнах. Бідні країни не змогли профінансувати протитуберкульозні заходи і епідемія туберкульозу в них прогресувала орієнтовно до 2005 року, і з 2006 року у більшості цих країн, як і в Україні, епідемія туберкульозу почала повільно відступати.

За даними ЄвроТБ (моніторингова структура ВООЗ), у 2010 році у світі зареєстровано 8,8 мільйона випадків захворювання на туберкульоз, 1,1 мільйона випадків смерті від туберкульозу серед осіб, що не мали ВІЛ-інфекції, і ще 0,35 мільйона випадків смерті від ВІЛ-асоційованого туберкульозу. Якщо взяти смертність ВІЛ-інфікованих за $100 \%$, то одна четверта з них помирає від туберкульозу.

У 2011 році 520 тис. дітей (0-14 років) у світі занедужали на туберкульоз і майже 64 тисячі померли від цієї хвороби і близько 10 мільйонів дітей залишилися сиротами в результаті смерті батьків від туберкульозу.

Біля однієї третини населення світу інфіковані мікобактеріями туберкульозу. А це означає, що 10 \% людей, інфікованих мікобактеріями туберкульозу, протягом свого життя можуть захворіти на туберкульоз, особливо це люди з ВІЛінфекцією, діабетом, курці, з поганим харчуванням, стресом тощо. А за рік один хворий на туберкульоз може інфікувати до 10-15 інших людей, з якими він контактуватиме.

За оціночними даними, одна третина випадків захворювання на туберкульоз в усьому світі не реєструється, тобто реальна ситуація безсумнівно гірша від статистично зареєстрованої.

Якщо глянути на карту світу, то побачимо, що, за даними 2010 року, при середньосвітовій захворюваності на туберкульоз 128 на 100 тис. населення і смертності 15 на 100 тис. населення лідируюче місце займала Африка (захворюваність - 276 на 100 тис. населення, смертність - 30 на 100 тис. населення);

на 2-му місці була Південно-східна Азія (відповідно 193 і 27 на 100 тис. населення);

на 3-му місці - Східний Середземноморський регіон (109 і 16 на 100 тис. населення);

на 4-му місці - Західний Тихоокеанський регіон (93 і 7,5 на 100 тис. населення);

на 5-му місці - Європа (47 і 6,8 на 100 тис. населення);

на 6-му місці - Америка (29 і 2,2 на 100 тис. населення.

Окрім того, ми проаналізували ситуацію у країнах цих частин світу з цієї глобальної статистики і виявили таку закономірність:

а) туберкульозу там більше, де гірший рівень життя і освіченості населення; наприклад, більше 95 \% випадків смерті від туберкульозу зареєстровано в країнах з низьким і середнім рівнем доходу громадян;

б) туберкульозу там більше, де гірше фінансуються протитуберкульозні заходи;

в) динаміка захворюваності й смертності прямо пропорційні, тобто іншими словами, якщо зростає захворюваність, то й зростає смертність; а якщо зменшується захворюваність, то й зменшується смертність; причому динаміка смертності в часі відстає приблизно на 2 роки від динаміки захворюваності.

Розрізняють три рівні захворюваності на туберкульоз у Європейському регіоні ВОО3:

1. Високий (захворюваність більше 30 на 100 тис. населення): Російська Федерація, Україна, Румунія, Узбекистан,
Казахстан, Білорусь, Киргизія, Таджикистан, Республіка Молдова, Азербайджан, Туркменістан, Литва, Грузія, Латвія, Вірменія, Болгарія, Боснія і Герцеговина.

2. Середній (захворюваність - 10-30 на 100 тис.): Туреччина, Іспанія, Польща, Португалія, Югославія, Угорщина, Хорватія, колишні Югославські республіки, Македонія, Албанія, Естонія, Мальта, Сербія, Великобританія.

3. Низький (захворюваність до 10 на 100 тис.): Німеччина, Франція, Італія, Греція, Нідерланди, Бельгія, Австрія, Данія, Швейцарія, Фінляндія, Ірландія, Ізраїль, Швеція, Норвегія, Люксембург, Андорра, Ісландія, Сан-Марино, Монако, Республіка Чехія, Республіка Словаччина, Словенія, Кіпр.

\section{Ситуація з туберкульозу довкола України}

Захворюваність на туберкульоз в Україні на 32 \% більше середньоєвропейської.

31995 р. в Україні зареєстрована епідемія туберкульозу. Вона, як і в інших країнах набула рис триєдиної епідемії, тобто містила три складові:

- перша складова - це епідемія типового туберкульозу, який спостерігався у доантибактеріальну еру, тобто такого туберкульозу, що добре піддається антимікобактеріальній терапії; вона включає до 80-90\% таких хворих в структурі захворюваності туберкульозом у різних регіонах країни;

- друга складова - це епідемія хіміорезистентного туберкульозу, насамперед йдеться про первинну резистентність мікобактерій туберкульозу до антимікобактеріальних препаратів - від 7 до 15 \% таких хворих;

— третя складова — це епідемія туберкульозу у поєднанні з ВІЛ-інфекцією та СНІДом, тобто ко-інфекція туберкульозу / ВІЛ (близько 5-10 \% таких хворих в структурі захворюваності на туберкульоз).

До 2006 року Україна не могла справитися з епідемією туберкульозу, оскільки з 1990 р. до 2000 р. не виділялися цільові кошти на закупівлю антимікобактеріальних препаратів, хворі лікувалися хаотично за свої кошти. Так, за 1990-2005 роки захворюваність на всі форми туберкульозу збільшилася в 2,64 раз (з 31,8 до 84,1 на 100 тис. населення), смертність від туберкульозу збільшилася в 2,88 раз (з 8,8 до 25,3 на 100 тис. населення). Це призвело до суттєвого зростання хіміорезистентності.

32000 р. почали централізовано закуповувати антимікобактеріальні препарати, запровадили стандарти і контрольованість лікування, у Міжнародного банку реконструкції та розвитку взята позика, отриманий грант Глобального фонду, зміцнена матеріальна база бактеріологічних лабораторій. Це привело до того, що з 2006 року епідемія туберкульозу вступила у фазу стабілізації. Так, за 2005-2011 роки захворюваність на всі форми туберкульозу знизилася з 84,1 на 100 тис. населення до 67,2 на 100 тис. населення, або на 20,1%. У 2001 р. захворюваність на туберкульоз складала 75,1; це означає, що ми ще далекі навіть від рівня 1995 року (41,6 на 100 тис. населення), коли була проголошена епідемія туберкульозу.

За 2005-2011 роки захворюваність на туберкульоз дітей 0-14 років зменшилася з 9,3 на 100 тис. дитячого населення до 8,0 на 100 тис. дитячого населення, або на 13,98 \%. За цим показником нині ми на рівні 2005 року (9,3 на 100 тис. дитячого населення).

За 2005-2010 роки смертність від усіх форм туберкульозу зменшилася з 25,3 на 100 тис. населення до 16,6 на 100 тис. 
населення, тобто на 34,39 \%, і за смертністю досягли рівня 1998 року (16,1 на 100 тис. населення), а у 1995 році було 15,0 на 100 тис. населення.

Найгірша ситуація з туберкульозу у південно-східному регіоні України та в установах пенітенціарної системи.

За останні кілька років збитки від туберкульозу в Україні складають близько 3,5 млрд. грн. на рік.

Хіміорезистентний туберкульоз. Хіміорезистентний туберкульоз $\epsilon$ у всіх країнах світу. В 2010 році у світі зареєстровано близько 650 тис. випадків мульти- й розширенорезистентного туберкульозу, з них у 9 \% випадків був туберкульоз із розширеною резистентністю. Причому з усіх цих хворих лише 16 \% отримують повноцінне лікування мульти- і розширенорезистентного туберкульозу. Померло 150 тис. чоловік від цієї форми туберкульозу.

В Європі зареєстровано 29059 хворих на мультирезистентний туберкульоз. Серед усіх мультирезистентних хворих Європи на країни Євросоюзу припадає 4,98 \% (1447 хворих), на країни не Євросоюзу 95,02 \% (27612 хворих), з них більше 80 \% хворих - у країнах колишнього СРСР.

Туберкульоз і ВІЛ. У світі 34 млн. людей ВІЛ-інфіковані, з них одна третина інфіковані мікобактеріями туберкульозу, але це ще не хворі на активний туберкульоз. Туберкульоз у 21-34 рази частіше виникає у ВІЛ-інфікованих порівняно з неінфікованими ВІЛ. У 2010 році близько 350 тис. чоловік померли від ко-інфекції туберкульоз / ВІЛ.

В Україні 7196 хворих на туберкульоз у поєднанні зі ВІЛ; за 2005-2011 роки контингент цих хворих збільшився з 3227 до 7196, або 2,19 рази, а смертність відповідно збільшилася з 3,0 до 6,1 на 100 тис. населення, або вдвічі.

\section{Причини незадовільної епідемічної ситуачії з туберку- льозу в Україні}

Чому Україну охопила хвиля туберкульозу?

Передусім слід відзначити, що незадовільна ситуація 3 туберкульозу на 90 \% залежить від соціально-економічних факторів, від влади, від політиків і лише на $10 \%$ - від медицини, від діяльності медичних працівників.

А. Сочіально-економічні й політичні фактори незадовільної ситуації з туберкульозу:

1) соціально-економічна криза в країні, що привела до:

- погіршення добробуту й освіченості народу;

- стресів, бідності, безробіття;

- зростання алкоголізму, наркоманії, токсикоманії, бездомних, жебраків та інших соціально-дезадаптованих верств населення;

- збільшення чисельності осіб у пенітенціарній системі;

- міграції населення і зростання груп ризику щодо туберкульозу;

1.1) соціально-економічна криза привела до погіршення фінансування охорони здоров'я, до кризи охорони здоров'я і непристосованості охорони здоров'я до ринкових умов, я це в свою чергу привело до:

• кадрової кризи (більше 60 \% фтизіатрів глибокого пенсійного віку);

- до поганого забезпечення лікувально-профілактичних закладів медичною апаратурою, обладнанням, ліками, соціальною підтримкою хворих;

• поганих санітарно-гігієнічних умов перебування і поганого харчування хворих у стаціонарах;
• недоступності медичної допомоги для більшості населення, особливо сільського;

• нестачі антимікобактеріальних, патогенетичних і симптоматичних препаратів;

• недоступності фтизіохірургічного лікування хворих через погане фінансування фтизіохірургічної допомоги;

Всі ці соціально-економічні й політичні фактори та криза в охороні здоров'я привели до:

- відсутності реформування, реорганізації та реструктуризації охорони здоров'я загалом і протитуберкульозної служби зокрема;

- невиконання в повному обсязі протитуберкульозних заходів через брак фінансування;

- прогресування епідемії туберкульозу і ВІЛ/СНІДу, в т. ч. хіміорезистентного туберкульозу та ко-інфекції туберкульозу/ ВІЛ/СНІДу, як серед всього населення так й у пенітенціарній системі, серед тих, що звільнилися з ув'язнення, бездомних, мігрантів, біженців, знедолених;

Б. Суто медичні фактори незадовільної ситуачії з туберкульозу:

- Недостатні навчання студентів і лікарів, слабкі вимоги до кваліфікації та атестації лікарів, через що:

- погані знання туберкульозу, особливо діагностики туберкульозу різних локалізацій, серед лікарів загальної медичної мережі й відмежування їх від цієї проблеми;

- недотримання контрольованості лікування хворих;

- недотримання стандартів діагностики й лікування хворих. Проблеми щодо туберкульозу в Україні

1. Однією з проблем, як ми вже зазначали, $\epsilon$ хіміорезистентний туберкульоз. В Україні частота первинної хіміорезистентності складає від 7 до 20 \% хворих в різних регіонах, а вторинна резистентність сягає 60-75\%. Туберкульоз із множинною лікарською стійкістю спостерігається майже у $9 \%$ нових хворих. Така статистика зумовлена тим, що до 2000 року в Україні централізовано не закуповувалися антимікобактеріальні препарати і хворі лікувалися хаотично: одним-двома препаратами замість 4-5, протягом 3-4 місяців замість $6-8$ місяців. В ці роки не було стандартів лікування, хворі не лікувалися контрольовано. Це привело до збільшення частоти стійкості мікобактерій туберкульозу до антимікобактеріальних препаратів. Це погана прогностична ознака щодо взяття під контроль епідемії туберкульозу.

2. Другої проблеми ми теж вже торкалися. Це туберкульоз у поєднанні з ВІЛ-інфекцією/СНІДом, або ко-інфекція: туберкульоз/ВІЛ/СНІД, або ВІЛ/СНІД-асочійований туберкульоз. Оскільки за останні роки приріст хворих на туберкульоз і ВІЛ/СНІД у деяких адміністративних територіях сягає до $20,00 \%$ за рік. Для них часто-густо не вистачає ні антимікобактеріальних препаратів II ряду, а ні антиретровірусних препаратів.

Більше 25 \% цих хворих, як правило, помирають. Через те треба ближче стикувати і координувати заходи контролю за туберкульозом та ВІЛ/СНІДом.

3. Незнання медичними працівниками загальної лікарняної мережі методів діагностики туберкульозу. За нашими даними, помилки діагностики туберкульозу на фельдшерсько-акушерських пунктах (ФАП) становлять 96,7-99,5 \%, помилки лікарів сільських амбулаторій та дільничних лікарень - 80,4-90,3 \%, помилки лікарів загального профілю центральних районних лікарень (ЦРЛ) - 54,2-72,1 \%, помилки міських і обласних лікарів загального профілю - 42,2-51,7 \%, помилки лікарів- 
фтизіатрів - 3,2-4,7 \%. Це й приводить до того, що хворі довго лікуються у лікарів загальної практики з приводу неспецифічної легеневої чи позалегеневої патології, а потім із занедбаними випадками туберкульозу потрапляють до фтизіатра.

4. Недостатнє впровадження в практику контрольованого лікування, особливо на амбулаторному етапі, та й навіть у багатьох протитуберкульозних стаціонарах. Ще у 1999 році постановою Кабінету Міністрів України від 23 квітня 1999 р. № 667 «Про Комплексні заходи боротьби з туберкульозом» передбачалось запровадження ставок патронажних медсестер для контрольованого лікування на амбулаторному етапі. Пізніше рекомендовано створити дОТ-кабінети, це кабінети для контрольованого лікування хворих. Але, на жаль, через брак фінансування досі не у всіх адміністративних територіях України все це впроваджено, а якщо і впроваджено, то погано спрацьовує. Оскільки втрачається контроль за вживанням антимікобактеріальних препаратів, то або формується хіміорезистентність, або таке лікування неефективне.

5. Залишається недостатнім харчування хворих на туберкульоз у стаціонарах. Харчування хворого на туберкульоз $\epsilon$ невід'ємною складовою його лікування. Вартість харчування хворого у стаціонарі за останні роки дуже низька і не доганяє інфляції та підвищення цін на продукти харчування. А це означає, що якщо хворі погано харчуються, не отримують достатньої кількості нутрієнтів з харчуванням, то погано переносять антимікобактеріальні препарати і через зниження імунітету погіршується ефективність лікування.

6. Викликає тривогу відсутність належного інфекційного контролю в протитуберкульозних закладах і через те висока захворюваність на нозокоміальний туберкульоз пацієнтів та зараження туберкульозом медичних прачівників. Через брак коштів сьогодні, окрім Донецька, немає сучасних відділень для хворих на хіміорезистентний туберкульоз, немає належних засобів колективного й індивідуального захисту від повітрекрапельної туберкульозної інфекції. Звідси хворий на хіміочутливий туберкульоз в стаціонарі може заразитися резистентним туберкульозом. Це стосується й медичних працівників. Якщо в 1990 році в Україні захворювало на туберкульоз 30 медичних працівників протягом року, то у 2000 р. - 788, у 2005 р. - 850, у 2011 р. Вже значно менше - 525.

7. Важливою проблемою $є$ й руйнування матеріально-технічної бази та скорочення кадрового потенціалу протитуберкульозної служби (додаток 5). Так, за $1990-2011$ роки ліквідовано 76 (41,09 \%) протитуберкульозних диспансерів, скорочено 13261 (37,04 \%) диспансерних ліжок, ліквідовано 45 (33,09 \%) протитуберкульозних санаторіїв і 11647 (48,58 \%) санаторних ліжок. До того ж, в Україні на 876 (24,17 \%) фтизіатрів стало менше (ї зараз 2748). Не завадило 6 в кожній із 27 адміністративних територій перепрофілювати хоч по одному-два протитуберкульозні санаторії для соціально-дезадаптованих хворих на туберкульоз, створити хоспіси. У дитячих протитуберкульозних відділеннях були школи, тому що діти лікуються довго. На початку 90-х років школи ліквідовані через брак коштів.

8. Пенітенціарна система України продовжує залишатися джерелом інфекції для цивільного населення. Особливо це стосується ув'язнених хворих на туберкульоз із множинною лікарською стійкістю. Хоча там ситуація поступово поліпшується, але не так, як хотілось би. Так, у слідчих ізоляторах захворюваність на туберкульоз складала у 2010 р. - 1002,3 на 100 тис. населення, у 2011 році — 744,8 на 100 тис. населення; у виправ- них колоніях: у 2010 році - 865,1, а у 2011 році - 773, 9 на 100 тис. населення. Це в 11,0 раз більше, аніж серед популяції. Там $\epsilon 10$ туберкульозних лікарень.

9. Сьогодні фтизіатрична служба забезпечена усіма необхідними нормативно-правовими документами, протоколами, стандартами. Проте фінансування для реалізації цієї законодавчої бази немає. I це є причина всіх невирішених проблем!

\section{Біологія мікобактерій туберкульозу}

До роду Micobacterium родини Micobacteriaceae включені кислото- і спиртостійкі аеробні нерухомі грампозитивні прямі або вигнуті паличкоподібні бактерії. Іноді вони утворюють нитковидні або міцеліальні структури, які фрагментуються при легкому механічному впливі на палички чи кокоподібні елементи.

Мікобактерії широко поширені в навколишньому середовищі - воді, ґрунті, у рослин і тварин. Рід нараховує більше 200 видів; типовий вид - Mycobacterium tuberculosis. За ознакою патогенності розрізняють власне патогенні, що спричиняють конкретні захворювання, і атипові мікобактерії, серед яких $\epsilon$ умовно-патогенні і сапрофітні.

M. tuberculosis - тонкі, прямі чи злегка вигнуті палички зі злегка закругленими кінцями, у цитоплазмі містять зернисті утворення. Іноді утворюють коковидні структури і L-форми, що зберігають патогенність, а також форми, що фільтруються, патогенна роль яких залишається недостатньо вивченою.

При мікроскопічному дослідженні мазків з колоній, забарвлених за Цілем-Нільсеном, виявляються яскраві малиновочервоні паличкоподібні бактерії, що розташовуються поодиноко або групами.

Лабораторна мережа України. На бактеріологічні лабораторії покладається особлива функція у питаннях діагностики заразних випадків захворювання на туберкульоз та моніторингу ефективності процесу лікування. Саме тому, важливим напрямком удосконалення та оптимізації роботи лабораторій протитуберкульозної служби України $\epsilon$ обов'язкова стандартизація основних бактеріологічних методів. Впровадження їх в роботу дозволяє отримати результати, які можуть бути порівняні з результатами досліджень інших лабораторій, що дає можливість своєчасно виявляти та реагувати на помилки в діагностиці, проводити оптимальне специфічне лікування хворих, оптимізувати та полегшити навчання фахівців, оцінити якість роботи лабораторій, окремих фахівців та проводити відповідний контроль ефективності лабораторних досліджень.

Для реалізації цього напрямку в Україні підготовлена низка організаційно-розпорядчих, нормативних та учбових матеріалів з питань структури лабораторної мережі, організації роботи та удосконалення лабораторної діагностики туберкульозу.

Лабораторна мережа з мікробіологічної діагностики туберкульозу організована за територіальним принципом і включає клініко-діагностичні лабораторії загально-лікарняної мережі і лабораторії протитуберкульозних закладів України, які за методами та обсягом досліджень поділяються на три рівні.

- Лабораторії І рівня (пункти мікроскопії), що створені на базі лабораторій лікувально-профілактичних закладів загальної лікувальної мережі і виконують мікроскопію досліджуваного матеріалу.

- Лабораторії II рівня, що створені на базі районних та міських протитуберкульозних закладів, виконують мікроскопію, 
посів досліджуваного матеріалу, попередню ідентифікацію виділених мікобактерій.

- Лабораторії III рівня, що створені на базі обласних та деяких міських, у тому числі Київського та Севастопольського міських протитуберкульозних закладів, виконують мікроскопію, посів досліджуваного матеріалу, виділених мікобактерій та визначення чутливості їх до протитуберкульозних препаратів.

Організаційним, науково-практичним і методичним центром $\epsilon$ Референс-лабораторія МОЗ і НАМН України, яка розташована на базі лабораторії мікробіології НІФП і виконує весь спектр мікробіологічних досліджень на туберкульоз; розробляє, апробує і впроваджує в практику сучасні методи досліджень; здійснює координацію роботи лабораторій III рівня, контроль за якістю всіх досліджень на туберкульоз в Україні.

Типові положення про лабораторії різного рівня викладені у наказі МОЗ України від 06.02.2006 р. № 50 “Про затвердження типових положень про лабораторії і пункти з діагностики туберкульозу та пункти забору мокротиння", зареєстрованому в Міністерстві юстиції України 30.05.2006 за №630/12504.

\section{Бактеріологічна діагностика туберкульозу}

Мікробіологічні дослідження з діагностики туберкульозу $\epsilon$ найважливішою складовою діагностичного процесу як на етапі постановки діагнозу "туберкульоз", так і при контролі ефективності хіміотерапії. Відповідно до наказу МОЗ України від 06.02.2002 р. № 45 “Про затвердження інструкції з бактеріологічної діагностики туберкульозної інфекції" в країні втілена система лабораторних досліджень діагностики туберкульозу, якою передбачено три етапи:

а) первинне (мікроскопічне) дослідження діагностичного матеріалу на наявність кислотостійких бактерій в закладах загально-лікувальної мережі;

б) комплексне мікроскопічне і культуральне дослідження діагностичного матеріалу в бактеріологічних лабораторіях протитуберкульозних закладів;

в) визначення чутливості до антимікобактеріальних препаратів і остаточна ідентифікація виділеного збудника в бактеріологічних лабораторіях протитуберкульозних закладів.

У лабораторії, в залежності від рівня діагностики, можуть виконуватися всі або тільки деякі з перерахованих досліджень.

Культуральний метод дослідження до сьогодні залишається "золотим стандартом" в діагностиці туберкульозу. Він дозволяє бактеріологічно верифікувати діагноз "туберкульоз", виділити культуру з діагностичних матеріалів, отриманих від олігобацилярних хворих, у тому числі і від хворих на позалегеневий туберкульоз та дітей. При добре організованому дослідженні вдається одержати культуру з матеріалів, що містять декілька сотень клітин мікобактерій. У разі використання рідких середовищ поріг чутливості знижується до декількох десятків клітин мікобактерій туберкульозу (МБТ).

Культуральний метод дозволяє виділити культуру збудника і визначити спектр чутливості до протитуберкульозних препаратів. Основний недолік методу - терміни виділення культури мікобактерій.

При використанні класичних щільних живильних середовищ на яєчній основі термін позитивного результату складає 3-5 тижнів, проте для окремих культур, особливо виділених від пацієнтів, які раніше отримували лікування, цей час перевищує 8 тижнів. Негативний результат видається після 8 тижнів куль- тивування. Використання рідких живильних середовищ значно скорочує терміни появи росту — до 10-20 діб для більшості культур. За рекомендаціями виробників автоматичних систем реєстрації росту мікобактерій, які працюють на рідких середовищах Міддлбрук, час видачі негативного результату, становить 42 доби.

Для посіву діагностичного матеріалу використовують різноманітні живильні середовища, серед яких можна виділити основні групи:

- щільні живильні середовища на яєчній основі;

- щільні або напіврідкі живильні середовища на агаровій основі;

- рідкі живильні середовища;

- рідкі синтетичні і напівсинтетичні живильні середовища.

Скорочення термінів культивування мікобактерій із збереженням або збільшенням чутливості та специфічності методу $\epsilon$ основним напрямком розвитку мікробіологічної діагностики туберкульозу в Україні.

Відомо, що рідкі середовища забезпечують більш швидке отримання результату порівняно з щільними. Фаза логарифмічного росту популяції мікобактерій досягається вже до 5-10го дня після інокуляції в рідке середовище матеріалу від хворого на туберкульоз. У той же час застосування рідких середовищ ускладнюється трудомістким процесом власної детекції розмноження мікобактерій, а також високим рівнем їх контамінації іншими мікроорганізмами.

Еволюція методів культивування мікобактерій у рідких середовищах відбувалася в напрямку розробки відносно дешевого і технічно доступного методу швидкої детекції, що здійснюється з найбільшим ступенем біозахисту персоналу.

У 1977 році G. Middlebrook описав спосіб радіометричної детекції росту мікобактерій в селективному рідкому середовищі, що поклало початок створення найбільш поширених і комерційно доступних систем бульйонного культивування: ВАСТЕС 460 (BD), BBL Septi-Chek AFB (BD), BBL MGIT (BD), BACTEC MGIT 960 (BD), MB/BacT (Organon Teknika) i BacT/Alert 3D (BioMerioux).

Радіометрична система ВАСТЕС 460 для вирощування та ідентифікації мікобактерій використовує рідке середовище Middlebrook 7H12. Впровадження ВАСТЕС 460 дозволило скоротити терміни виявлення збудника туберкульозу до 14 днів, а також проводити швидку ідентифікацію комплексу $M$. tuberculosis і визначати чутливість мікобактерій до медикаментозних препаратів. В індустріально розвинених країнах система ВАСТЕС 460 отримала широке розповсюдження.

При очевидних перевагах, радіометрична система ВАСТЕС 460 має ряд недоліків - таких, як напівавтоматичний моніторинг росту культури, значна трудомісткість операцій, робота 3 радіоізотопами і необхідність утилізації радіоактивних відходів. Для їх подолання була запропонована більш досконала технологія флуоресцентної реєстрації росту мікроорганізмів, яка лягла в основу розробки мануальної (неавтоматизованої) системи BBL MGIT (BD), що з'явилася в лабораторіях з 1994 року.

Принцип флуоресцентної детекції росту був використаний при розробці повністю автоматизованої системи бульйонного культивування мікобактерій ВАСTEC MGIT 960, яка $\epsilon$ найбільш досконалою серед існуючих аналогічних систем, широко поширена в лабораторіях всього світу, у тому числі і в Україні. Вона являє собою повністю автоматизований комплекс для одночасної інкубації та моніторингу 960 пробірок. Дана систе- 
ма дозволяє виявляти у клінічних зразках більшість штамів мікобактерій туберкульозу протягом 10-20 днів і визначати чутливість культури збудника до медикаментозних препаратів в термін, що не перевищує двох тижнів.

Медикаментозна стійкість мікобактерій та їі визначення. Стійкість мікобактерій туберкульозу до протитуберкульозних препаратів $\epsilon$ однією $з$ найсерйозніших проблем сучасної фтизіатрії.

Велике значення для ухвалення конкретних рішень про проведення терапії хворого на туберкульоз має структура резистентності мікобактерій туберкульозу до препаратів.

Відповідно до міжнародних стандартів розрізняють наступні категорії стійкості МБТ до ПТП.

Монорезистентність - стійкість тільки до одного (будьякого) протитуберкульозного препарату.

Полірезистентність - стійкість до двох і більше протитуберкульозних препаратів, за виключенням резистентності одночасно до ізоніазиду та рифампіцину.

Мультирезистентність (або MDR від англ. Multy Drug Resistance) - це особлива категорія серед полірезистентних штамів, у яких $\epsilon$ стійкість до ізоніазиду та рифампіцину одночасно, незалежно від резистентності до інших препаратів.

Лікування хворих з мультирезистентними МБТ має особливі труднощі, оскільки ізоніазид і рифампіцин залишаються до теперішнього часу найбільш ефективними ПтП.

У 2006 році в міжнародній класифікації з'явився новий термін - розширена медикаментозна резистентність (XDR). Це стійкість, принаймні, до ізоніазиду, рифампіцину, фторхінолонів і до одного з трьох ін'єкційних препаратів (капреоміцину, канаміцину або амікацину).

Для оцінки епідемічної ситуації в міжнародній практиці прийнято розрізняти стійкість мікобактерій до медикаментозних препаратів у раніше не лікованих (первинну) і лікованих хворих (набута).

Стійкість мікобактерій до медикаментозних препаратів у раніше не лікованих хворих визначається як стійкість, виявлена у мікобактерій, виділених від пацієнта, що ніколи не лікувався від туберкульозу або одержував лікування менше одного місяця.

В даному випадку вважається, що хворий заразився штамом мікобактерій стійким до медикаментозних препаратів. Первинна стійкість до антимікобактеріальних препаратів характеризує стан мікобактеріальної популяції, циркулюючої на даній території, i iї показники є важливими для оцінки ступеня напруженості епідемічної ситуації.

Стійкість мікобактерій у хворих, що раніше не лікувались, має велике клінічне і епідеміологічне значення, тому для правильної їі оцінки надзвичайно важливо досліджувати культуру, виділену з діагностичного матеріалу, зібраного до початку лікування.

Частота стійкості до медикаментозних препаратів у раніше не лікованиххворих визначається як відношення кількості вперше виявлених хворих на туберкульоз з резистентними мікобактеріями туберкульозу до всіх обстежених вперше виявлених бацилярних хворих за певний період (як правило, квартал, календарний рік).

Стійкість до медикаментозних препаратів мікобактерій у раніше лікованих хворих визначається як стійкість, що виявлена у хворого на туберкульоз, який одержував лікування протягом одного місяця.
Частота набутої стійкості до медикаментозних препаратів визначається як відношення кількості раніше лікованих хворих на туберкульоз з резистентними мікобактеріями туберкульозу до всіх обстежених раніше лікованих бацилярних хворих за певний період (як правило, квартал, календарний рік).

Стійкі до антимікобактеріальних препаратів бактерійні клітини виникають в популяції інфекційних бактерій в організмі господаря. При дії на неї протитуберкульозного препарату чутливі до нього клітини гинуть, а стійкі бактерії одержують селективні переваги для виживання і розповсюдження в організмі.

При застосуванні монотерапії, зменшених доз або укорочених курсів лікування виникає ситуація, що сприяє виживанню і розповсюдженню форм стійких до антимікобактеріальних препаратів. Частота виникнення одночасно двох мутацій, що призводять до стійкості до двох препаратів, значно нижче, ніж для однієї, що приводить до моностійкості. Проте при застосуванні другого препарату для лікування інфекції, вже стійкої до одного з препаратів, і при недостатній ефективності терапії в організмі хворого виникне популяція бактерій, стійких вже до двох антибактеріальних препаратів. Таким чином, розповсюдження стійкості до антимікобактеріальних препаратів $\epsilon$ наслідком неадекватної хіміотерапії і вважається явищем, створеним людиною. Для подолання можливого множення стійкості до медикаментозних препаратів у фтизіатрії застосовується хіміотерапія не менше, ніж 4-ма протитуберкульозними препаратами.

Проблема розвитку і розповсюдження медикаментозної стійкості у фтизіатрії загострюється у зв'язку з обмеженістю спектру антимікобактеріальних препаратів, ефективних при цьомузахворюванні, ітривалістю курсулікування.Переривання лікування, відмова від прийому препаратів, самолікування $\epsilon$ основними причинами наростання стійкості збудників туберкульозу до антимікобактеріальних препаратів.

Для визначення стійкості мікобактерій повинні використовуватися тільки стандартизовані методи дослідження, що дозволяють:

- правильно вести лікування пацієнтів;

- інтерпретувати і порівнювати дані, одержані з різних джерел;

- проводити оцінку рівнів стійкості до медикаментозних препаратів, а також тенденцій, які спостерігаються в різних регіонах або країнах.

В даний час немає єдиного універсального методу визначення чутливості мікобактерій туберкульозу. Існують культуральні методи з використанням щільних і рідких живильних середовищ 3 автоматичною детекцією росту мікобактерій, а також молекулярно-генетичні експресні методи. Вибір того або іншого методу визначається методичними підходами, що традиційно склалися і використовуються в даній країні. Для ефективного управління моніторингом, забезпеченням епідеміологічного нагляду за стійкістю мікобактерій до медикаментозних препаратів і розповсюдженням стійких штамів збудника, а також для порівнювання результатів досліджень і ефективності лікування в межах світової спільноти в маситабах кожної країни рекомендується використовувати тільки один з наявних уніфікованих методів, регламентований внутрішніми нормативними документами країни.

Всі наявні методи визначення чутливості мікобактерій туберкульозу можна умовно розподілити на 2 категорії: 
- методи прямого визначення чутливості мікобактерій туберкульозу;

- методи непрямого визначення чутливості мікобактерій туберкульозу.

Методи прямого визначення чутливості мають низку недоліків, але основним $є$ неможливість стандартизувати методику.

При використанні методів непрямого визначення чутливості мікобактерій туберкульозу проводиться виділення мікроорганізмів з клінічних зразків при культивуванні, а потім на середовище, що містить препарат, висівається гомогенна суспензія культури.

Відомі три основних класичних мікробіологічних методи непрямого визначення чутливості мікобактерій туберкульо3y.

- Memod пропорцій, запропонований в 1963 році Canetti, Rist and Grosset і деталізований в 1985 p. Middlebrook and Cohn.

- Метод абсолютних концентрачій на щільних і рідких середовищах, модифікований в 1970 році Meissener.

- Метод коефіuієнта стійкості, розроблений в 1961 році Mitchison та іншими авторами.

3 класичних культуральних методів визначення чутливості мікобактерій до протитуберкульозних препаратів найбільш відомий метод пропорцій, в теперішній час загальноприйнятий в Україні, який дозволяє встановити, яка частина мікобактеріальної популяції у відсотковому відношенні $\epsilon$ стійкою до даного препарату.

Молекулярно-генетичні методи діагностики туберкульозу

Скорочення термінів виявлення збудника, видової ідентифікації мікобактерій, визначення медикаментозної чутливості мікобактерій може бути досягнена за рахунок застосування у лабораторній практиці молекулярно-генетичних методів. Їх використання у діагностиці туберкульозу дозволяє при госпіталізації хворого в стаціонар у найкоротші терміни детектувати медикаментозну стійкість мікобактерій, виявляти нетуберкульозні мікобактерії і призначати адекватний режим хіміотерапії в інтенсивну фазу лікування, що скорочує терміни припинення бактеріовиділення (абацилювання), підвищує ефективність лікування, запобігає поширенню штамів мікобактерій, стійких до протитуберкульозних препаратів.

В основі молекулярно-генетичних методів діагностики туберкульозу лежить полімеразно-ланцюгова реакція (ПЛР), що набула широкого поширення в діагностиці різних інфекційних агентів, в тому числі мікобактерій туберкульозу.

Принцип методу полімеразно-ланцюгової реакції полягає в ампліфікації - багаторазовому збільшенні ділянок специфічної послідовності ДНК мікобактерій туберкульозу в пробірочному мікрооб'ємі при циклічному повторенні трьох стадій реакції, кожна з яких проходить в умовах різного температурного режиму:

- 1-а стадія - зміна структури ДНК (денатурація) при нагріванні з розмежуванням їі ланцюгів;

- 2-а стадія - зв'язування з денатурованою ДНК синтетичних послідовностей нуклеотидів (праймерів або «затравочних» олігонуклеотидів), комплементарних до кінцевих ділянок фрагменту ДНК, специфічного для мікобактерій туберкульозу;

- 3-я стадія - синтез або добудова ланцюга обмеженого по флангах фрагменту ДНК за допомогою термостабільної ДНК-полімерази.
Багаторазове подвоєння специфічних фрагментів ДНК призводить до збільшення їх кількості в геометричній прогресії до рівня, який дозволяє здійснити детекцію існуючими методами. Результати полімеразно-ланцюгової реакції оцінюють як з допомогою агарозного гельелектрофорезу, при якому оцінюється розмір фрагменту ДНК, що утворився в порівнянні зі стандартними фрагментами ДНК з відомим числом пар нуклеотидів (за відстанню пробігу від старту у вигляді флуоресціюючої смужки), так і за допомогою різних методів гібридизації продукту зі специфічними комплементарними міченими ДНКзондами.

У 1998 році був повністю розшифрований геном мікобактерії туберкульозу. Це дозволило виділити специфічні для генома мікобактерій туберкульозу нуклеотидні послідовності ДНК, які використовуються при виявленні збудника туберкульозу в різних видах діагностичного матеріалу методом полімеразно-ланцюгової реакції.

Сьогодні за рекомендаціями Всесвітньої організації охорони здоров'я (ВОО3) запропоновано два методи молекулярної діагностики, які можуть бути використані для вирішення питання своєчасної діагностики туберкульозу - технологія ДНК-cmpuniв ma GeneXpert.

ДНК-стрипова технологія дозволяє швидко визначити збудника туберкульозу та його чутливість до протитуберкульозних препаратів.

Для виявлення та ідентифікації мікобактерій ДНК-стрипова технологія використана у наборах виробництва Hain Lifescience (Німеччина). Тривалість власне дослідження як такого невелика і становить 4-5 годин.

Технологія GeneXpert рекомендована ВОО3 до застосування у діагностиці туберкульозу лише з 2010 року. Система GeneXpert дозволяє наступне:

- виділення та ампліфікація проводиться в картриджі, попередня обробка діагностичного матеріалу зводиться до мінімальних маніпуляцій;

- можливість контамінації значно скорочується;

- визначає стійкість мікобактерій туберкульозу лише до рифампіцину.

Набір реагентів для mecmy Xpert MTB/RIF призначено для використання з системою GeneXpert ${ }^{\circledR}, \epsilon$ напівкількісною гніздовою полімеразною ПЛР в реальному часі в пробірці, що проводиться з метою виявлення:

а) ДНК мікобактерій туберкульозу у зразках мокроти або концентрованих осадів мокроти;

б) мутацій резистентності до рифампіцину гена гров у зразках, отриманих від пацієнтів з ризиком резистентності до даного препарату.

Тест призначений для дослідження зразків від пацієнтів, у яких є клінічні ознаки туберкульозу легень.

За даними ВОO3, резистентність до рифампіцину свідчить про резистентність до ізоніазиду. Резистентність до рифампіцину і ізоніазиду (мультирезистентність) зазвичай свідчить про необхідність одночасного проведення повного тестування на чутливість до препаратів першого і другого ряду, але це можливо тільки після виділення культури мікобактерій.

Система GeneXpert Dx (власне прилад для тестування) включає автоматизовану обробку зразків, ампліфікацію нуклеїнових кислот і визначення послідовності в зразках, яка нас цікавить, з використанням методів полімеразно-ланцюгової реакції (ПЛР) у реальному часі та полімеразно-ланцюгової 
реакції із зворотною транскриптазою. Система вимагає використання одноразових картриджів GeneXpert, що містять реагенти для полімеразно-ланцюгової реакції, в яких і відбувається реакція. Оскільки картриджі $\epsilon$ автономними, перехресна контамінація зразків не можлива.

\section{Патогенез туберкульозу}

Туберкульозна інфекція починає розвиватись в організмі людини з моменту попадання мікобактерії туберкульозу (МБТ) з частинками інфекційної аерозолі із повітря до альвеол. Якщо інфікування відбувається вперше, відбувається взаємодія між мікобактеріями туберкульозу і альвеолярними макрофагами, які ще не $\epsilon$ специфічно активованими. Розів'ється захворювання, чи збудник буде знищений — залежить від співвідношення мікробоцидної здатності макрофагів та вірулентності мікобактерії, до процесу залучаються неактивовані моноцити з кровотоку, які нездатні до ефективного фагоцитозу. Вони захоплюють мікобактерії туберкульозу, але завершений фагоцитоз не відбувається, і мікроорганізм отримує можливість логарифмічно розмножуватись внутрішньоклітинно. Макроорганізм реагує на це спробою знищити середовище для росту мікобактерій туберкульозу і викликає апоптоз, опосередкований, зокрема, фактором некрозу пухлин. У сухому казеозному некрозі мікобактерії туберкульозу практично не розмножуються. Гіперактивація макрофагів у певний момент починає відбуватися на користь мікобактерій туберкульозу, оскільки намагаючись фагоцитувати занурені у казеоз бактерії, вони виділяють надмірну кількість бактерицидних агентів, які руйнують казеозні маси, далі з оточуючих тканин осмотично засмоктується вода, що призводить до розрідження казеозу. Рідкий казеоз $є$ прекрасним поживним середовищем для позаклітинного розмноження мікобактерій туберкульозу. Розріджені маси казеозу швидко видаляються через дренуючий бронх із формуванням порожнини деструкції. Пізня фаза розвитку хвороби характеризується утворенням пневмонії, фокального некрозу та поширеного інтерстиціального фіброзу, що розвиваються впродовж 2-го місяця процесу.

Активний туберкульоз розвивається лише у $10 \%$ людей, в організм яких попала мікобактерія туберкульозу. В інших випадках імунна система контролює розмноження мікобактерії і збудник персистує в лімфатичних вузлах та альвеолярних макрофагах - латентна туберкульозна інфекція. При первинному інфікуванні захворювання розвивається в осіб із неповноцінною імунною системою (насамперед, у ВІЛінфікованих) і у дітей. У ВІЛ-інфікованих розвиваються генералізовані форми туберкульозу, у дітей - первинний туберкульозний комплекс - вогнище в легенях та ураження регіональних внутрішньогрудних лімфатичних вузлів на стороні ураження легень.

В інших випадках захворювання розвивається при реактивації латентної туберкульозної інфекції внаслідок ослаблення імунної системи або екзогенної суперінфекції. В цих випадках виникають вторинні форми туберкульозу із локальним ураженням легень або інших органів, оскільки імунна система вже активована мікобактерією туберкульозу.

\section{Діагностика туберкульозу}

Своєчасна діагностика туберкульозу і його лікування - це основний захід профілактики туберкульозу спрямований на переривання ланцюга передачі інфекції. Тому вимоги щодо швидкості, простоти і специфічності діагностичних методів насамперед обумовлені епідеміологічними міркуваннями.

На сьогодні рентгенологічні методи не рекомендовані до масового скринінгу. Вони також не повинні застосовуватись без інших методів для діагностики туберкульозу, оскільки не $\epsilon$ специфічними і сприяють гіпердіагностиці.

Численні наукові дослідження щодо вивчення специфічності комп'ютерної томографії у діагностиці туберкульозу легень довели високу специфічність методу (до 98 \%) при наявності одночасно 5 ознак, притаманних для туберкульозу: наявність вогнищ, каверн, лобулярних ущільнень, кальцинатів, бронхіальних уражень.

За відсутності одночасно цих 5 ознак специфічність методу різко знижується. Інфільтрат в легенях, що обумовлений туберкульозом не можливо відрізнити від пневмонії та раку легень.

Наступний метод, який багато років застосовується для виявлення туберкульозу, - мікроскопія мазка мокротиння за методом Циля-Нільсена. Переваги цього методу полягають у дешевизні, швидкості та здатності виявляти заразні випадки туберкульозу. Метод не $\epsilon$ високоспецифічним, він дозволяє виявляти лише кислото стійки бактерії, найпоширенішими 3 яких $\epsilon$ мікобактерія туберкульозу. Проте можлива контамінація з оточуючого середовища не патогенними мікобактеріями, яким також притаманна кислотостійкість. Мікроскопія мазка мокротиння на кислотостійкі бактерії (КСБ) не дозволяє розрізнити життєздатні та нежиттєздатні M. tuberculosis ні мікроорганізми, чутливі та резистентні або мікроорганізми, що належать до різних штамів M. tuberculosis. Значення мікроскопії обмежується можливістю визначення найбільш заразних пацієнтів, сортування зразків мокротиння для різних алгоритмів культурального дослідження і проведення тесту медикаментозної чутливості (ТМЧ). Подальше отримання росту підтверджує те, що КСБ були дійсно мікобактеріями туберкульозу, а не контамінацією матеріалу з оточуючого середовища.

Золотим стандартом діагностики туберкульозу $\epsilon$ виділення мікобактерії туберкульозу культуральним методом на спеціальні живильні середовища, а саме на тверде живильне середовище Левенштейна-Йенсена, яке містить куряче яйце. Це високо специфічний метод діагностики туберкульозу, і з високою чутливістю (до 95 \%) дозволяє верифікувати діагноз туберкульозу, якщо у мокротинні міститься $10-100$ особин мікобактерій туберкульозу у мілілітрі. Суттєвим недоліком методу $\epsilon$ тривалий час для отримання результату (до 8 тижнів), оскільки мікобактерія належить до мікроорганізмів, що повільно розмножуються.

Гістологічні методи верифікації діагнозу при дослідженні біоптатів уражених органів в сучасних умовах поширення ВІЛінфекції втрачають своє значення, оскільки у ВІЛ-інфікованих осіб через імунодефіцит не формується типова туберкульозна гранульома, на підставі якої діагностують туберкульоз.

Мікобактерію можна вирощувати також на рідких середовищах, які містять конячу сироватку. В останні 10 років з'явились нові прискорені культуральні методи вирощування мікобактерій на рідкому середовищі за допомогою автоматичного аналізатору. Метод заснований на індикації росту мікобактерій туберкульозу в рідкому поживному середовищі за споживанням кисню, оскільки мікобактерії належать до класу облігатних аеробів. Ріст мікобактерій, який невидимий для ока людини, можна зафіксувати на апараті вже через 7-14 днів. До 
недоліків методу належать висока вартість та дотримання сурових вимог експлуатації апарату.

Хоча посів мокротиння на рідкі середовища на мікробіологічному аналізаторі значно скорочує час верифікації діагнозу, цей метод все ж таки $\epsilon$ відносно довготривалим.

В умовах епідемії туберкульозу із поширенням резистентних форм захворювання потрібна негайна діагностика туберкульозу для своєчасної ізоляції і лікування хворого з метою переривання ланцюга інфекції.

3 відкриттям геному мікобактерії туберкульозу у 90-х роках минулого сторіччя почали швидко розвиватись молекулярно-генетичні методи швидкої діагностики туберкульозу.

Недоліком молекулярно-генетичних методів $\epsilon$ те, що такі тести можуть давати хибні негативні та хибні позитивні результати. Хибні поз итивні результати можуть - хоча й нечасто - виникати через забруднення зразка мікобактеріями середовища, що спричиняє неспецифічне зв'язування 3 зондом. Хибні негативні результати зустрічаються частіше, зокрема через малу кількість мікроорганізмів або, у деяких типах зразків. Специфічність і чутливість тестів порівнювалася з результатами щодо захворювання, підтвердженими культурою. Проте, оскільки 20-30 \% випадків легеневого туберкульозу і ще більша частка позалегеневого туберкульозу не підтверджуються культурою, то результативність молекулярних тестів у цих умовах оцінити важко.

\section{Лікування хворих на туберкульоз}

3 часів стародавніх Греції та Єгипту до середини XX століття людство намагалося знайти способи лікування туберкульозу, про що свідчить довгий перелік різних методів - кровопускання, кліматотерапія, ліжковий режим, вживання жирів, перерізка діафрагмального нерву, пневмоторакс, пневмоперитонеум, олеоторакс, торакопластика. Сотні відомих людей померли від туберкульозу, маючи доступ до кращих лікарів їх епохи. Тільки з появою стрептоміцину в 1943 році туберкульоз перестав бути фатальною хворобою. Одночасно в Європі синтезована парааміносаліцилова кислота, а у 1952 році відкритий найефективніший протитуберкульозний препарат ізоніазид. Методика застосування протитуберкульозних препаратів розроблялася суто емпірично шляхом застосування індивідуальних схем відповідно до тяжкості захворювання. Хаотичне, безсистемне, різне за тривалістю застосування цих ліків дуже швидко призвело до виникнення нової суттєвої проблеми - медикаментозної резистентності збудника туберкульозу, зниження ефективності протитуберкульозних препаратів.

Мікробіологічними дослідженнями того часу встановлено, що МБТ належать до облігатних аеробів з повільним розмноженням (кожні 20-30 год.) і неминучим виникненням у процесі розмноження мутантів, резистентних до антибактеріальних препаратів. Ці відомості, а також дані численних клінічних досліджень ефективності застосування протитуберкульозних препаратів ізольовано і в комбінаціях стали підставою для розробки основних принципів лікування туберкульозу, які залишились актуальними до сьогодні:

- застосування стандартних комбінацій антибактеріальних препаратів (для попередження селекції резистентних мутантів та розвинення медикаментозної резистентності мікобактерій туберкульозу);
- призначення хіміопрепаратів у добових дозах за один прийом для створення максимальної бактеріостатичної концентрації у крові;

- основний курс хіміотерапії туберкульозу тривав до повного припинення бактеріовиділення, зникнення запальних явищ в легенях. Ефективна тривалість лікування у разі застосування режиму 3-х протитуберкульозних препаратів ізоніазиду, стрептоміцину та ПАСК - 12 міс.

Був розроблений стандартний режим хіміотерапії (ізоніазид + стрептоміцин + ПАСК 12 місяців), який дозволив суттєво поліпшити епідеміологічну ситуацію щодо туберкульозу захворюваність в різних країнах світу почала знижатися щорічно на 5-7 \%, ефективність лікування досягла 40-70 \% за показником припинення бактеріовиділення.

3'явилися нові протитуберкульозні препарати - тіоацетазон, піразинамід, циклосерин, але вони мали низькі протитуберкульозні властивості, а етамбутол і етіонамід - помірні, тому суттєво не вплинули на результати лікування хворих на туберкульоз. Проте завдяки цим препаратам, були розроблені нові стандартні режими хіміотерапії, які відрізнялись кращою переносимістю, ніж у разі застосування ПАСК. У 60-70-ті роки XX століття в світі спостерігалось стабільне зниження захворюваності на туберкульоз (на 5 \% щорічно), смертності і майже незмінні результати хіміотерапії - 50-70 \%.

Ситуація суттєво змінилась в середині 70-х років та на початку 80-х років, коли було відкрито протитуберкульозні властивості рифампіцину, який за активністю не відрізнявся від ізоніазиду. Отримана нова інформація про мікобактеріальну популяцію і механізм дії протитуберкульозних препаратів. Ці відомості стали новим концептуальним етапом розвитку хіміотерапії туберкульозу.

Популяція мікобактерій туберкульозу складається з типових бактерій, що швидко і повільно розмножуються, і персистуючих форм. У вперше діагностованих хворих на туберкульоз із звичайним перебігом захворювання до початку лікування популяція мікобактерій туберкульозу складається з 80 \% бактерій, що швидко ростуть, $15 \%$ - що ростуть повільно, 5 \% що персистують. Під дією протитуберкульозних препаратів співвідношення у популяції мікобактерій туберкульозу швидко (з 5-10-го дня) змінюється у бік збільшення персистуючих форм. У разі монотерапії на 7-10-й день лікування у бактеріальній популяції з'являються резистентні і залежні від антимікобактеріальних препаратів мікобактерії туберкульозу. Форми мікобактерій туберкульозу, що змінилися під дією лікування, не втрачають своєї патогенності й легко реверсують у початкові форми (крім резистентних) після припинення дії несприятливого чинника. Встановлено, що на мікобактерії туберкульозу, які активно розмножуються, бактерицидно впливають ізоніазид і рифампіцин, бактеріостатично - стрептоміцин та етамбутол. Одночасно були відкриті унікальні властивості піразинаміду - бактерицидний вплив на персистуючі внутрішньоклітинно розташовані мікобактерії туберкульозу (до того часу вважали, що піразинамід бактеріостатично діє проти зовнішньоклітинно розташовані мікобактерії туберкульозу в казеозних масах).

Усі ці відомості стали підставою для розробки нових, дуже важливих принципів хіміотерапії туберкульозу.

1. Двоетапність лікування туберкульозу: перша інтенсивна щоденна фаза (бактерицидна дія протитуберкульозних препаратів проти мікобактерій туберкульозу, що активно, повільно 
розмножуються та персистують), друга - підтримуюча інтермітуюча або щоденна.

2. Тривалість основного курсу скорочена до 6-8 міс завдяки бактерицидному впливу ізоніазиду, рифампіцину, піразинаміду на всі форми мікобактерій туберкульозу, що активно розмножуються та персистують.

Численними дослідженнями ефективності короткострокових курсів хіміотерапії доведена ії оптимальна тривалість - 6 міс у разі МБТ-негативних форм туберкульозу і 7-8 міс — у разі МБТ-позитивних форм.

3'являються нові стандартні схеми лікування туберкульозу:

Ізоніазид + рифампіцин + стрептоміцин 2 місяці, а потім ізоніазид + рифампіцин через день 4 місяці - для МБТнегативних вперше діагностованих форм; ізоніазид + рифампіцин + стрептоміцин + піразинамід 2 місяці, а потім ізоніазид + рифампіцин + піразинамід через день 6 місяців - для МБТпозитивних вперше діагностованих форм.

Ці режими хіміотерапії дозволяли досягти 95-100 \% ефективності у разі застосування у вперше діагностованих хворих серед вибіркових контингентів пацієнтів (з високим рівнем сприяння лікуванню, без ускладнених і задавнених форм туберкульозу) і у 60-85 \% - у загальній популяції, яка включала тяжкі або хіміорезистентні форми туберкульозу.

Але наприкінці $80-x$ років і початку $90-x$ років епідеміологічна ситуація щодо туберкульозу раптово погіршилась. Захворюваність в усіх країнах світу підвищилась на 20-100 \%, зросла смертність, погіршились показники ефективності лікування, значно зросла медикаментозна резистентність мікобактерій туберкульозу до протитуберкульозних препаратів.

1992 рік став етапом, коли більшість країн світу повернулися обличчям до загрози світової епідемії туберкульозу після 20 років ігнорування цієї проблеми. Зростання захворюваності на туберкульоз і спалах мультирезистентного туберкульозу у великих містах (Нью-Йорк, 1993) стали рушійною силою в об'єднанні світових зусиль для подолання цієї загрози.

Епідеміологічні дослідження показали, що 95 \% усіх випадків туберкульозу припадало на країни, що розвиваються. 3 початку 90-х років у країнах Африки і колишнього Радянського союзу захворюваність на туберкульоз зростала відповідно на $10 \%$ і $7 \%$ на рік.

Впроваджені 3 70-х років багатокомпонентні режими хіміотерапії повинні були попереджати виникнення медикаментозної резистентності, але вони не використовувались в повному обсязі, що було зумовлено рядом причин. Найбільш поширеною причиною була відсутність державної фінансової і законодавчої підтримки, національних стратегій по лікуванню туберкульозу, погане сприяння лікуванню, епідемія ВІЛінфекції в Африці, погіршення соціально-економічних умов у країнах Східної Європи. У 1992 році тільки 15 країн світу мали національні програми боротьби з туберкульозом. 3 урахуванням негативного досвіду впровадження в широку практику найефективнішого протитуберкульозного препарату рифампіцину (мультирезистентність з'явилась і зросла тільки в країнах, де його широко застосовували) наукові та фінансові зусилля світової громадськості для подолання загрозливої ситуації щодо туберкульозу були спрямовані не на розробку нових ліків, а на заходи, спрямовані на розрив ланцюга передачі інфекції- виявленню заразних форм захворювання та їх ефективне лікування шляхом забезпечення регулярного прийому протитуберкульозних препаратів.
Зважаючи на це ВООЗ у 1993 році проголосила глобальну небезпеку з туберкульозу. За ініціативою ВООЗ у 1993 році була розроблена стратегія контролю над туберкульозом, яка гарантує найкращий спосіб застосування протитуберкульозних препаратів, що існують - короткострокове лікування під прямих наглядом - DOTS (Directly Observed Treatment Shortcourse), що означає "суворо контрольоване лікування коротким курсом антимікобактеріальної терапії".

\section{Cтратегія DOTS складається 35 компонентів:}

1. Державна підтримка контролю і надзору за туберкульозом (уряд країни має підтримувати стратегію DOTS та фінансувати їі, залучаючи неурядові організації. Для цього необхідна програма уряду щодо впровадження DOTS та навчання медичних працівників з питань реалізації DOTS.

2. Виявлення випадків захворювання на туберкульоз за зверненням методом мікроскопії мазка.

3. Лікування захворювань на туберкульоз (безпосереднє спостереження за проведенням стандартизованого короткого курсу лікування).

4. Регулярне безперервне постачання протитуберкульозних препаратів гарантованої якості через ефективну систему їх закупівель.

5. Моніторинг та оцінка результатів лікування (стандартна система реєстрації та звітності, яка заснована на квартальному когортному аналізі).

Ці 5 компонентів DOTS-стратегії спрямовані на досягнення наступної мети: виявлення 70 \% бацилярних форм туберкульозу (серед усіх форм туберкульозу) і досягнення припинення бактеріовиділення у 85 \% хворих, що пройшли повний курс хіміотерапії.

Названі цифри $\epsilon$ загальними для інфекційних хвороб. Згідно законам виникнення епідемії інфекційних захворювань, якщо виявляти не менше 70 \% найнебезпечніших хворих, які виділяють збудника хвороби в оточуюче середовище, серед усіх захворілих і виліковувати не менше 85 \%, то буде перерваний ланцюг передачі інфекції, що призведе до зниження захворюваності.

31994 року в багатьох країнах світу почали впроваджувати нову стратегію і в 2000 році 148 країн (у тому числі 22 країни 3 найвищою захворюваністю на туберкульоз), у яких зареєстровано 80 \% усіх випадків туберкульозу, прийняли DOTSстратегію. Це призвело до значного прогресу в лікуванні туберкульозу, але значно меншого у виявленні бацилярних форм туберкульозу.

Нажаль в умовах епідемії ВІЛ-інфекції і зростання мультирезистентності збудника туберкульозу DOTS-стратегія не дозволяє досягти значного прогресу у лікуванні туберкульозу.

Враховуючи позитивний досвід DOTS-стратегії, її недоліки (неможливість діагностувати туберкульоз у дітей та туберкульоз без бактеріовиділення), ії обмеження у зв'язку з поширенням мультирезистентного туберкульозу та ВІЛ-інфекції в 2006 році прийнята нова стратегія боротьби з туберкульозом StopTB. Вона включає 6 елементів:

а) покращення якості DOTS-стратегії (бактеріологічна діагностика туберкульозу та туберкулінодіагностика у дітей);

б) вирішення особливих задач щодо ВІЛ-асоційованого та мультирезистентного туберкульозу;

в) посилення системи охорони здоров'я з питань контролю над туберкульозом; 
г) залучення всіх медичних працівників до виконання туберкульозної програми;

д) надання підтримки пацієнтам і залучення громадськоCTi;

е) проведення наукових досліджень та заохочення до їх проведення.

Отже сучасна стратегія лікування туберкульозу StopTB спирається на принципи DOTS-стратегії та доповнена новими елементами, які дозволяють якісно проводити контроль за туберкульозом. Після встановлення діагнозу туберкульозу негайно розпочинають лікування, оскільки тільки антимікобактеріальна терапія спроможна перервати передачу туберкульозної інфекції. Розроблено Уніфікований клінічний протокол медичної допомоги (УКПМД) «Туберкульоз» згідно наказу МО3 від 21.12.2012 № 1091, який є стандартом лікування хворих різних категорій в усіх закладах країни.

Існують докази, що шестимісячний початковий режим із застосуванням чотирьох препаратів (ізоніазіду та рифампіцину протягом шести місяців з доданням у перші два місяці піразинаміду та етамбутолу) слід застосовувати для лікування активного ТБ органів дихання у:

- дорослих, у котрих ВІЛ-статус негативний або невідомий;

- дорослих з ВІЛ-позитивним статусом;

- дітей.

Стандартизована терапія хворим на ТБ складається з двох фаз: інтенсивної (ІФ) та підтримуючої (ПФ). Хворі при проведенні ІФ лікування отримують від 4 до 6 ПТП (залежно від категорії). В ПФ хворі отримують від 2 до 4 ПТП залежно від категорії. Лікування хворих в ПФ (в ІФ - за умови відсутності бактеріовиділення) може бути організоване в амбулаторних та/ або санаторних умовах, тому що такі хворі не становлять епідеміологічної загрози для оточуючих їх осіб.

\section{Необхідні діі лікаря}

- Початкова хіміотерапія (ПФ) для хворих 1, 2, 3 категорій:

ізоніазид + рифампіцин + піразинамід + етамбутол - 2 місяці щоденно;

ізоніазид + рифампіцин - 4 місяці щоденно або через день. Режим дозування з прийомом тричі на тиждень допустимий тільки у разі ДОТ, але не застосовується для пацієнтів 3 ко-інфекцією ТБ/ВІЛ. Режим дозування з прийомом двічі на тиждень не застосовують для лікування ТБ.

- За результатами ТМЧ або клінічними результатами при невдачі лікування здійснюється корекція схеми лікування.

- Препарати приймаються за один прийом усередину із розрахунку відповідно до маси тіла. Комбіновані ПТП з фіксованими дозами у будь-якому режимі лікування ТБ.
- 4 категорія хворих (МР ТБ, РР ТБ, поліРезист ТБ):

1) ПФ згідно з даними ТМЧ (за призначенням обласної ЦЛКК-ХРТБ) протягом 12 місяців із застосуванням не менше 4-х ПТП (не менше 3-х препаратів II ряду).

Стандартизоване контрольоване лікування всім хворим на ТБ проводиться за інформованою згодою пацієнта з дотриманням вимог інфекційного контролю з метою попередження подальшого розповсюдження захворювання на ТБ та попередження розвитку МР ТБ.

\section{Необхідні дії лікаря}

У стаціонарних умовах проводять лікування пацієнтам 1, 2 кат. в інтенсивній фазі (ІФ) основного курсутерапії. Призначають 4 препарати щоденно протягом 2-3 місяців, але не менше 60 та не більше 90 доз.

Пацієнтам 3 категорії проведення лікування в стаціонарних умовах можливе при наявності медичних показань (тяжкі супутні захворювання, непереносимість ПТП).

Лікування пацієнтів 4 (МР ТБ) категорії здійснюється в умовах спеціалізованих відділень (або ізольованих палат з негативним тиском).

Стаціонарне лікування проводиться пацієнтам всіх категорій до припинення бактеріовиділення, що підтверджується методом мікроскопії мазка мокротиння.

Лікування дітей з локальними формами ТБ проводиться в умовах стаціонару або спеціалізованого санаторію.

Лікування нових випадків та рецидивів захворювання проводять тільки протитуберкульозними препаратами I ряду (табл. 1).

Як свідчать дані табл. 1 найактивнішими препаратами I ряду є рифампіцин та ізоніазид, які мають бактерицидну дію у відношенні мікобактерій туберкульозу. Решту препаратам властива лише бактеріостатична дія. Піразинамід хоча й має невисоку мінімальну інгібуючу концентрацію (МIK) у відношенні мікобактерій туберкульозу, проте він бактерицидно діє на усі форми мікобактерій туберкульозу (розташовані, як поза-, так і внутрішньоклітинно, ті що діляться та ті, що знаходяться у стані спокою).

Загалом протитуберкульозні препарати I ряду переносяться добре і викликають тяжкі побічні реакції не більше ніж у 3-5 \% хворих. Серед цих пацієнтів переважають особи 3 вірусними та хронічними гепатитами, тяжкою медикаментозною алергією.

В таблиці 2 наведено дозування протитуберкульозних препаратів відповідно до маси тіла, які використовують для лікування хворих на хіміорезистентний туберкульоз (моно-, полі, мульти-, розширена резистентність).

\section{Дозування протитуберкульозних препаратів}

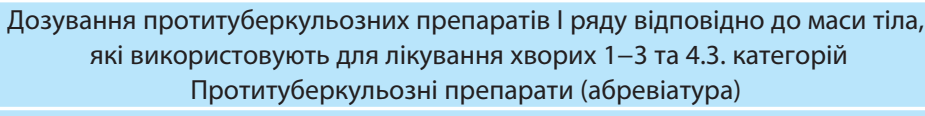

\section{Ізоніазид (H)}

Рифампіцин(R)

Піразинамід (Z)

Стрептоміцин (S)

Етамбутол (E) щоденний

\begin{tabular}{|c|c|}
\hline $\mathrm{Mг} / \mathrm{K} \Gamma$ & $\Gamma$ \\
\hline $5(4-6)$ & $0,3-0,45$ \\
\hline $10(8-12)$ & 0,6 \\
\hline $25(20-30)$ & $1,5-2,0$ \\
\hline $15(12-18)$ & 1,0 \\
\hline $15(15-20)$ & $1,2-1,6$ \\
\hline
\end{tabular}

Рекомендовані дози для ПТП 1 групи

через день або 3 рази на тиждень $\mathrm{Mr} / \mathrm{K} \Gamma$

$10(8-12)$

$10(8-12)$

35 (30-40)

$15(12-18)$

$30(25-35)$

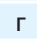

0,6

0,6

$2,5-3,0$

1,0

$1,6-2,0$ 
Табличя 2

Дозування протитуберкульозних препаратів відповідно до маси тіла, які використовують для лікування хворих на хіміорезистентний туберкульоз (моно -, полі, мульти -, розширена резистентність) [Уніфікований протокол, 2012 р.]

Препарат, доза у од 33 кг
1 група: протитуберкульозні препарати
Ізоніазид (H) 4-6 мг/кг`щоденно або
8-12 мг 3 рази на тиждень
Рифампіцин (R)
Етамбутол (E)
Піразинамід (Z)
2 група: ін'єкційні ПтП
Стрептоміцин (S) (1 г)
Канаміцин (Km) (1 г)
Амікацин (Аm) (1 г)
Капреоміцин (Cm) (1 г)
3 групи: фторхінолони
Офлоксацин (Ofx) (200, 300,400 мг)
Левофлоксацин (Lfx) (250 мг, 500 мг)
Моксифлоксаци н (Mfx) (400 мг)
Гатифлоксацин (Gfx) (400 мг)

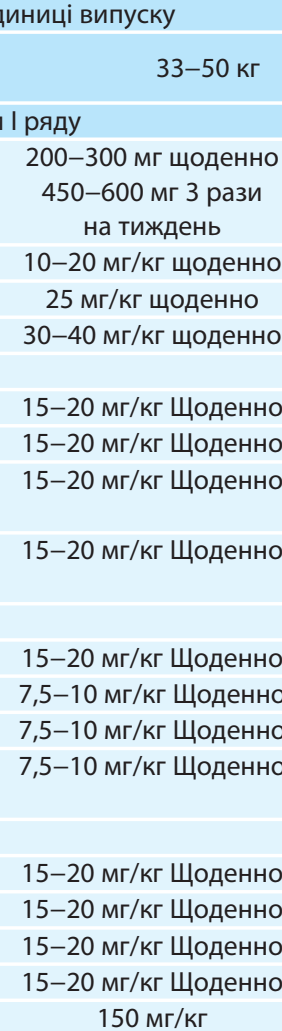
$150 \mathrm{Mr} / \mathrm{Kr}$

Препарат, доза у одиниці випуску

Кислота (PAS) (4 г на одиницю виміру)

Натрієва сіль пара-аміносаліцилової кислоти

Тіоцетазон (Th)
5 група: препарати з невизначеною ефективністю (не рекомендуються для рутинного застосування у хворих на МР ТБ, за необхідності застосовуються для хворих на РРТБ, якщо відсутні інші можливості для формування схеми з 4-х ПтП з 1-4 груп) Клофазимін (Cfz)

Амоксициллін клавуланова кислота (Amx/Clv)

Кларитроміцин (Clr)

Лінезолід (Lzd)

Ізоніазид у високих дозах

Препарат, доза у одиниці випуску

Кислота (PAS) (4 г на одиницю виміру)

Натрієва сіль пара-аміносаліцилової кислоти Тіоацетазон (Th)
100-300 мг для дорослих. Деякі лікарі починають з 300 мг і зменшують дозу до 100 мг через 4-6 місяців лікування

875-125 мг двічі на день або 500/125 мг тричі на день. Дозування у 1000/250 мг також використовувалося, але побічні ефекти можуть обмежити таке дозування 500 мг для дорослих двічі на день

600 мг для дорослих двічі на день. Зазвичай лікарі зменшують дозу до 600 мг один раз на день через 4-6 місяців лікування для зменшення побічних ефектів

16-20 мг/кг щоденно. Застосовують тільки як додатковий препарат п'ятий препарат у схемі лікування при задовільній переносимості

\section{Маса тіла}

Щоденно

Доза залежить від форми випуску (дивитися в інструкції до препарату) 150 мг для дорослих

5 група: препарати 3 невизначеною ефективністю (не рекомендуються для рутинного застосування у хворих на МР ТБ, за необхідності застосовуються для хворих на РРТБ, якщо відсутні інші можливості для формування схеми з 4-х ПтП з 1-4 груп) Клофазимін (Cfz)

Амоксициллін клавуланова кислота (Amx/Clv)

Кларитроміцин (Clr)

Лінезолід (Lzd)

Лінезолід (Lzd)

Ізоніазид у високих дозах

100-300 мг для дорослих. Деякі лікарі починають з 300 мг і зменшують дозу до 100 мг через 4-6 місяців лікування

875-125 мг двічі на день або 500/125 мг тричі на день. Дозування у 1000/250 мг також використовувалося, але побічні ефекти можуть обмежити таке дозування 500 мг для дорослих двічі на день

600 мг для дорослих двічі на день. Зазвичай лікарі зменшують дозу до 600 мг один раз на день через 4-6 місяців лікування для зменшення побічних ефектів

600 мг для дорослих двічі на день. Зазвичай лікарі зменшують дозу до 600 мг один раз на день через 4-6 місяців лікування для зменшення побічних ефектів

16-20 мг/кг щоденно. Застосовують тільки як додатковий препарат п'ятий препарат у схемі лікування при задовільній переносимості 
Серед протитуберкульозних препаратів II ряду бактерицидну дію мають тільки фторхінолони. Препарати цієї групи слід призначати за даними ТМЧ. За активністю у відношенні МБТ in vitro та на тваринних моделях фторхінолони розподіляються наступним чином: моксифлоксацин = гатіфлоксацин > левофлоксацин > офлоксацин = ципрофлоксацин. Отже, моксифлоксацин та гатіфлоксацин високоактивні у відношенні МБТ, левофлоксацин - високоактивний, офлоксацин та ципрофлоксацин - менш активні.

Препарати 4 групи додають до стандартного режиму ХТ (2) та індивідуального режиму (1-3) на підставі даних ТМЧ, анамнезу попереднього лікування, ефективності цих препаратів, переносимості та їх вартості.

Препарати групи 5 не рекомендуються, як правило, для рутинного застосування при лікуванні хворих на МР ТБ через недостатній клінічний досвід їх застосування та недоведену в рандомізованих дослідженнях ефективність. їх призначають у разі розширеної медикаментозної резистентності МБТ, коли неможливо забезпечити адекватний режим XТ з препаратами груп 1-4.

Протитуберкульозні препарати II ряду відрізняються гіршою переносимістю, ніж препарати I ряду і викликають тяжкі побічні реакції в $20-30 \%$ хворих.

Протитуберкульозні препарати використовують лише у стандартних комбінаціях, які визначаються клінічною категорією обліку хворого.

Сучасні схеми лікування хворих на вперше діагностований туберкульоз легень забезпечують високу ефективність лікування. Зазвичай припинення бактеріовиділення досягають в $90 \%$ хворих, які звершили основний курс хіміотерапії. Проте, на сьогодні в Україні до 30 \% хворих дочасно припиняють лікування, що негативно впливає на показники ефективності. 3 урахуванням пацієнтів, які перервали лікування відсоток ефективного лікування в Україні становить 60-65 \%, що набагато нижче встановленого ВООЗ критерію - 85 \%. Перевагою схем лікування хворих з новими випадками туберкульозу $\epsilon$ низька вартість. Вартість препаратів в схемах лікування нових випадків та рецидивів захворювання становить відповідно 250 та 400 грн.

Неуспішне лікування серед пацієнтів з високою прихильністю до протитуберкульозної хіміотерапії спостерігають тільки у разі визначення хіміорезистентної форми захворювання або у разі виникнення тяжких побічних реакцій, які унеможливлюють проведення повноцінної хіміотерапії.

Отже на сьогодні слабкою ланкою в протитуберкульозному лікуванні $\epsilon$ його тривалість, через яку значна кількість хворих перериває основний курс хіміотерапії, що призводить до формування хронічних та хіміорезистентних форм захворювання. Цей недолік вказує на необхідність застосування нових інструментів у лікуванні туберкульозу. Одним з таких інструментів було впровадження нових антибактеріальних засобів, які мають активність у відношенні мікобактерій туберкульозу (фторхінолони), а також більш активних препаратів, які дозволять скоротити курс хіміотерапії і тим самим покращати сприяння лікуванню.

Прогресивним у цьому напрямку була розробка рифампіцинів подовженої дії (рифапентин) і широке застосування фторхінолонів для лікування туберкульозу. Однак потрібний новий препарат з принципово відмінним механізмом дії щодо мікобактерій туберкульозу. Наше розуміння туберкульозної бактерії і її взаємодії з людиною революційно змінилось. У 1998 році, коли був опублікований повний геном M. tuberculosis H37Rv, революційно змінилось наше розуміння туберкульозної бактерії і її взаємодії з людиною. Це означає, що розкрито багато нових мішеней впливу на мікобактерії туберкульозу. Було розроблено декілька нових хімічних сполук, що впливають на мікобактерії туберкульозу, а саме нітроімідазопиран РА-824, який може бути основою нового протитуберкульозного препарату. РА-824 ушкоджує мікобактерії туберкульозу за двома механізмами - порушення синтезу білка і жирних кислот, що відрізняє його від усіх протитуберкульозних препаратів. В лабораторних тестах ця субстанція має виражений бактерицидний ефект у відношенні мікроорганізмів, що розмножуються і персистують. Вважається, що цей препарат дозволить скоротити курс лікування. Однак його поява ще потребує значних коштів і часу - препарат знаходиться тільки на II стадії випробовувань.

Незважаючи на нові можливості для розробки протитуберкульозних препаратів, лишається дуже багато перешкод на шляху від наукових розробок до впровадження нового препарату у медичну практику, насамперед фінансові. На розробку нового препарату від синтезу молекули до клінічних випробовувань необхідно 500 млн. дол. США, а увесь фармакологічний ринок країн, що розвиваються, не перевищує 350 млн. дол. США. Створення Світового альянсу по розробці протитуберкульозних ліків (Лондон, 1998) було спрямовано на об'єднання світових інтелектуальних і фінансових, державних і приватних зусиль для розробки нового препарату.

Сьогодні вже проводяться експериментальні та клінічні дослідження по скороченню основного курсу хіміотерапії за рахунок використання у схемах лікування моксифлоксацину, який має високу бактерицидну дію у відношенні до мікобактерій туберкульозу. За даними експериментальних робіт на тваринних моделях (миші) схеми лікування, які включають моксифлоксацин дозволяють в більш короткі терміни досягти відсутності росту колоній мікобактерій туберкульозу з ушкоджених органів. Планується скоротити курс лікування до 2-х місяців. Проте, щоб остаточно визначитись з терміном лікування хворих з новими випадками туберкульозу необхідно проводити велику кількість клінічних досліджень з вивченням не тільки безпосередніх, а й віддалених результатів за кількістю рецидивів туберкульозу.

Підсумовуючи вищенаведене, можна заключити, що на сьогодні в Україні проводять лікування туберкульозу згідно з міжнародними стандартами. В Україні зареєстровані та застосовуються усі відомі протитуберкульозні препарати I та II ряду для лікування нових та повторних випадків захворювання. Протитуберкульозні препарати призначаються тільки у стандартних схемах хіміотерапії, які визначаються клінічною категорією хворих.

Ефективність лікування хворих з новими випадками туберкульозу недостатня за рахунок пацієнтів, які дочасно переривають лікування. Серед пацієнтів, які завершують основний курс хіміотерапії, виліковування досягають в 90 \% випадків. Неуспішне лікування серед цих хворих спостерігають за рахунок мультирезистентних форм захворювання або виникнення тяжких побічних реакцій.

Значна тривалість лікування хворих з новими випадками захворювання (6-8 місяців) потребує планування наукових досліджень по скороченню терміну основного курсу хіміотерапії за рахунок застосування нових протитуберкульозних препаратів. 
Профілактика туберкульозу

Профілактика туберкульозу включає 2 компоненти - первинну та вторинну профілактику.

Первина профілактика полягає у попередженні інфікування та реінфікування мікобактеріями туберкульозу, вторинна - у попередженні розвитку активного туберкульозу у інфікованих осіб.

Своєчасна діагностика, ізоляція заразного хворого та ефективне лікування - це основні компоненти первинної профілактики туберкульозу, які спрямовані на переривання ланцюга передачі інфекції.

Інші методи первинної профілактики спрямовані на попередження зараження за допомогою впровадження заходів інфекційного контролю за туберкульозом шляхом:

- адміністративного контролю (розділення потоків хворих, раціонального розміщення відділень у протитуберкульозному закладі, ізоляції заразних хворих до припинення бактеріовиділення методом мікроскопії мазка мокротиння);

- інженерного контролю за навколишнім середовищем (вентиляційних систем та використання ламп ультрафіолетового випромінювання);

- особистого захисту органів дихання (гігієна кашлю хворих, хірургічні маски у хворих бактеріовиділювачів, респіратори 3 гепафільтрами у медичного персоналу, який працює 3 хворими, які мають позитивний мазок мокротиння).

Важливим профілактичним заходом в контролі за туберкульозом $\epsilon$ первинна профілактика туберкульозу за допомогою щеплення вакциною БЦЖ, яка названа на честь науковців, які її розробили - А. Кальмета та К. Герена. Ця вакцина - жива і містить ослаблені особини мікобактерій бичачого штаму.

Перша вакцина БЦЖ була отримана в 1921 році шляхом багаточисельних циклів пасерування ізоляту мікобактерій бичачого штаму протягом 13 років. В результаті наступних циклів пасерування в різних лабораторіях були отримані різні вакцинальні штами з фенотиповими та генетичними відмінностями. Для попередження подальших відхилень від першої вакцини БЦЖ ВООЗ із 1956 зберігає ліофілізовані (сухі) посівні серії вакцинальних штамів. Нові партії вакцини отримують із посівного матеріалу шляхом його культивування в штучних умовах на поживних середовищах. Через 6-9 днів культура вилучається із поживного середовища, фільтрується, концентрується, гомогенізується та розбавляється перед ліофілізацією остаточного продукту. Розведена вакцина містить як живі, так і вбиті мікобактерії. Кількість культивованих бацил та біохімічний склад вакцини варіюють залежно від штаму та способу її виготовлення. Існує велика кількість штамів вакцини БЦЖ, проте, на французький пастерівський штам 1173 Р2, данський та токійський штам, штам фірми „Глаксо" приходиться $90 \%$ вакцинацій у світі. За ефективністю жоден штам не виділяється серед інших і не існує консенсусу у відношенні того, який штам слід застосовувати для вакцинації дітей.

В Україні тривалий час до 2008 року застосовували вакцину БЦЖ штаму Росія-1. 32008 року почали застосовувати вакцину штаму SSI (Данія).

При первинній імунізації під впливом вакцини БЦЖ мобілізується Т- та В-система імунітету. Стимуляція клітинного імунітету проявляється підвищенням фагоцитуючої активності макрофагів та супроводжується розвитком гіперчутливості уповільненого типу. Вакцина БЦЖ має доведений захисний ефект у відношенні розвитку туберкульозного менінгоенце- фаліту та дисемінованого туберкульозу у дітей. Ці форми захворювання у дітей навіть при наявності лікування $\epsilon$ смертельно небезпечними. За даними метааналізу опублікованої літератури щодо протективної дії вакцини БЦЖ доведено, що вона захищає від розвитку менінгіту в 73 \% випадках, міліарного туберкульозу - в 77 \% випадків. Аналіз випадків смерті дітей від туберкульозу в Україні показав, що у $96 \%$ дітей був відсутній знак БЦЖ.

За останні роки вакцинація БЦЖ дозволила врятувати тисячі життів. Проте, вона не захищає від інфікування туберкульозом, не попереджає реактивацію латентної туберкульозної інфекції в активне захворювання i, таким чином, має обмежений вплив на передачу мікобактерій туберкульозу в популяції.

Основним недоліком цієї вакцини $\epsilon$ недостатня імуногенність i, таким чином, недостатня превентивна дія у відношенні захворювання на туберкульоз. Забезпечити достатню імуногенність, не збільшуючи реактогенність живої вакцини (реакцію на вакцину з боку організму), досить складно. Збільшення кількості живих бактерій штаму Mycobacterium bovis у вакцинальній дозі підвищує імуногенність вакцини і одночасно кількість післявакцинальних ускладнень, у тому числі випадків розвитку активного туберкульозу, викликаного вакцинальним штамом Mycobacterium bovis. Тому актуальним $\epsilon$ розробка нової вакцини, яка б забезпечувала адекватну імунну (Т-клітинну) відповідь, що необхідно для довготривалого й ефективного захисту від туберкульозу. Серед цих нових розробок заслуговує на увагу вакцина з посиленими антигенними властивостями або вакцина з додатковими антигенами, які мають стимулюючу дію на Т-клітини імунної системи. Обидві вакцини на тваринних моделях більш ефективні, ніж БЦЖ. Випробовується також вакцина, яка містить ДНК мікобактерій. В даний час ці вакцини підготовлені для клінічних випробовувань.

Незважаючи не те, що БЦЖ далека від ідеалу вакцини, в країнах з високим тягарем туберкульозу, який перевищує епідемічний бар'єр (50 випадків на 100 тис. населення), навіть в країнах, де поширена ВІЛ-інфекція, всі діти грудного віку мають отримати одну дозу вакцини БЦЖ. Побічні реакції від вакцини, навіть у ВІЛ-інфікованих немовлят без клінічних проявів ВІЛінфекції, зустрічаються вкрай рідко. В країнах із низьким тягарем туберкульозу вакцинацію БЦЖ можна обмежити в групах ризику. Отже, незважаючи на недоліки, вакцинація БЦЖ в більшості економічних країн являється життєзберігаючим та важливим елементом стандартних заходів боротьби із туберкульозом. В Україні проводиться 3-х разове щеплення вакциною БЦЖ при народженні та 2 ревакцинації в 7 та 14 років. Про якість внутрішньошкірних щеплень БЦЖ свідчать формування шкірних знаків на місці введення вакцини, за наявністю та розміром яких визначають ефективність вакцинації та оцінюють розвиток післявакцинального імунітету.

На сьогодні ВООЗ проголошує, що вакцинація усіх здорових новонароджених в країнах із високим тягарем туберкульозу $є$ обов'язковою. Користь від вакцинації БЦЖ дітей, що народжені від матерів, із невідомим ВІЛ-статусом, перевищує ризик розвитку захворювання внаслідок інфікування вакцинальним штамом. Ці діти повинні бути вакцинованими. Ризик розвитку захворювання внаслідок інфікування вакцинальним штамом перевищує користь від вакцинації у дітей, в яких підтверджена ВІЛ-інфекція. Ці діти не повинні бути вакцинованими.

Вторинна профілактика туберкульозу полягає у застосуванні профілактичних курсів протитуберкульозного лікування 
з використанням ізоніазиду протягом 6 місяців або ізоніазиду у сполученні з етамбутолом або піразинамідом протягом 3-х місяців у інфікованих осіб з високим ризиком захворювання на туберкульозу. Зважаючи на поширеність медикаментозної резистентності і для попередження їі розвитку на сьогодні контингенти для проведення вторинної профілактики туберкульозу обмежені лише:

- дітей та підлітків;

- дорослих, які були у близькому контакті з хворими на заразну форму туберкульозу: ВІЛ-інфіковані особи;

- хворі на ревматичні захворювання. Яким призначають інгібітори фактору некрозу пухлин.

У пацієнтів, які перехворіли на туберкульоз протирецидивні курси не застосовують через їх неефективність.

Координація ефективних дій боротьби з туберкульозом, які передбачають насамперед сучасну діагностику, лікування та профілактику, повинна проводитись при постійній співпраці між країнами для створення єдиного руху проти туберкульозу та за підвищення здоров'я усіх членів суспільства. Боротьба з туберкульозом $\epsilon$ глобальним суспільним благом і потребує глобальних дій. Епідемія туберкульозу не буде подолана, якщо ми не об'єднаємо наші ресурси, найкращі методи та практику, а також інструменти усередині країни та за їі межами.

В результаті підвищення політичного сприяння боротьбі 3 туберкульозом був розроблений план поширення стратегії «Зупинити туберкульоз» для того, щоб зупинити поширення туберкульозу в Європейському регіоні. Держави-члени Європейського регіону ВООЗ підтримали цей план на сесії Європейського регіонального комітету ВООЗ. Європейський план $\epsilon$ своєрідним зразком та керівництвом для мобілізації та координації людських та фінансових ресурсів, необхідних для поширення належного контролю над туберкульозом і боротьби з ним в Регіоні, для того щоб досягти глобальних цілей ВОО3 по боротьбі з туберкульозом.

Прогноз щодо туберкульозу в світі та в Україні

Експерти ВООЗ прогнозують, якщо епідемію туберкульозу не взяти під контроль, то до 2020 року кількість інфікованих мікобактеріями туберкульозу досягне 2 млрд, з яких 150 млн. занедужають і 36 млн помруть. За їх даними, в найближчі роки ситуація з туберкульозу знову може погіршитися, бо «розгул» мультирезистентної мікобактерії нині практично не можна обмежити.

Експерти ВООЗ припускають, що щорічний приріст хіміорезистентного туберкульозу становитиме 300 тис. нових випадків, у 80 \% випадків можлива стійкість до трьох із п'яти антимікобактеріальних препаратів I ряду. Найчастіше це стрептоміцин, ізоніазид і рифампіцин.

За прогнозами ВООЗ, з 2011 до 2015 року в світі більше 2 млн нових випадків туберкульозної інфекції виявляться полірезистентними.

Якщо не взяти під контроль епідемію ВІЛ/СНІДу, то це теж сприятиме погіршенню ситуації з туберкульозу, оскільки майже у 15 \% ВІЛ-інфікованих розвивається туберкульоз і більше $25 \%$ з них помирає.

До того ж, до 2050 року близько 40 млн курців можуть померти від туберкульозу, бо ризик їх захворіти в 2,0 рази більший, аніж у некурців.

Причому більшість випадків захворювання на туберкульоз буде у країнах Африки, Середземномор'я й Азії.
За даними російських фахівців, у найближчі 15 років загальна кількість хворих на туберкульоз в Росії може зрости з 91687 (у 2010 році) до 1 млн. чоловік. А якщо в країні буде реалізована програма боротьби з бідністю і якщо на одного члена родини дохід буде становити не менше $250 €$ єро на місяць при збереженні темпів інфляції на рівні 8-9 \% за рік, то тоді загальна кількість хворих на туберкульоз скоротиться до 250300 тис. чоловік за рік і захворюваність буде становити не більше 40 випадків на 100 тис. населення й не більше 400-500 випадків у пенітенціарних закладах.

10-річний прогноз ситуації в Україні свідчить:

а) при соціально-економічних умовах в Україні гірших, аніж сьогодні, та

неприборкані епідемії ВІЛ-інфекції та росту хіміорезистентного туберкульозу, захворюваність на туберкульоз через 10 років може збільшитися в 2-2,5 рази, а смертність - в 2,53,0 рази;

б) при соціально-економічних умовах в країні таких же, як сьогодні захворюваність і смертність від туберкульозу може стабілізуватися $з$ повільною хвилеподібною тенденцією до зменшення - захворюваності - на $(2,7 \pm 0,5) \%$, смертності - на $(1,5 \pm 0,5) \%$ щороку;

в) при соціально-економічних умовах в Україні кращих, аніж сьогодні, i/або приборканні епідемії ВІЛ-інфекції та контролю за хіміорезистентним туберкульозом, захворюваність може зменшуватися на 3,0-5,0 \% щороку, а смертність може зменшуватися на 5,0-7,0 \% щороку.

Заходи щодо поліпшення контролю за туберкульозом в україні

У світі відомі чотири системи контролю за туберкульо30M.

1. Планова радянська система.

2. ДОТС-стратегія, яка в Україні адаптована.

3. дОТС-плюс-стратегія.

4. Стоп ТБ стратегія.

Стоп ТБ стратегія $\epsilon$ найповнішою і найефективнішою. ІІї слід адаптувати до українських національних умов і впроваджувати. Однак, оскільки всі заходи Стоп ТБ стратегії одночасно неможливо реалізувати через брак коштів, матеріальних і кадрових ресурсів, то ми вважаємо за доцільне впроваджувати заходи поетапно.

А. Що стосується медичних заходів, то вони ґрунтуються на заходах адаптованої Стоп ТБ стратегії:

Ha 1-му етаnі слід забезпечити раціональне лікування всіх хворих на туберкульоз, бо лікування $\epsilon$ найкращим заходом профілактики туберкульозу, оскільки вже через 3-4 тижні лікування хворий, хоч і виділяє мікобактерії туберкульозу, але вони настільки ослаблені, що не здатні заразити здорових. Насамперед слід:

- налагодити систему безперервного забезпечення хворих антимікобактеріальними препаратами I та II ряду гарантованої якості;

- забезпечити контрольоване лікування усіх хворих на належному рівні у стаціонарах і амбулаторно при соціальній підтримці хворих;

•дооснастити мережу бактеріологічних лабораторій необхідним обладнанням, живильними середовищами, кадрами;

- проводити імунопрофілактику й хіміопрофілактику туберкульозу згідно чинних стандартів; 
- організувати навчання фахівців стандартам діагностики, лікування, профілактики й моніторингу туберкульозу.

Ha 2-му еmani слід забезпечити максимальне виявлення хворих у групах ризику та у загальній медичній мережі:

- забезпечити інфекційний контроль у протитуберкульозних закладах, організувати відділення для хіміорезистентного туберкульозу;

- створити національний і регіональні комп'ютерні реєстри хворих і забезпечити моніторинг протитуберкульозних заходів;

- проводити санітарно-освітню роботу серед населення щодо симптомів туберкульозу, заходів профілактики, дотримання правил особистої гігієни;

- проводити навчання лікарів загальної медичної мережі щодо виявлення туберкульозу легень і позалегеневої локалізації, проведення контрольованого лікування у II фазі продовження;

На 3-му етапі слід:

- провести паспортизацію протитуберкульозних закладів, зокрема зробити аналіз та інвентаризацію всієї інфраструктури протитуберкульозної служби та провести їі реорганізацію і реструктуризацію;

- переглянути структуру протитуберкульозних санаторіїв, деякі $з$ них перепрофілювати для соціально-дезадаптованих хворих на туберкульоз, на базі інших - створити хоспіси, решту санаторіїв та ліжок перепрофілювати для хворих на активний туберкульоз і проведення в них основного курсу антимікобактеріальної терапії;
• планово зміцнювати матеріально-технічну базу і кадровий потенціал протитуберкульозної служби;

- впроваджувати решту заходів Стоп ТБ стратегії.

Б. Що стосується соціально-економічних заходів:

- постійно поліпшувати соціально-економічний розвиток суспільства,

поліпшувати добробут та освіченість нашого народу;

- провести комплекс загальнодержавних заходів для стабілізації та приборкання епідемії ВІЛ-інфекції, мульти- й розширенорезистентного туберкульозу.

Індикатори поліпшення контролю за туберкульозом та викорінення його

Поліпшення контролю за туберкульозом і невпинне поліпшення епідемічних показників з цієї недуги можливе за досягнення таких показників:

а) якщо серед прогнозованих нових випадків туберкульозу у $70 \%$ буде виявлене бактеріовиділення;

б) якщо буде вилікувано 85 \% бактеріовиділювачів;

в) якщо основні епідемічні показники (захворюваність, поширеність, смертність) будуть зменшені на 50 \% порівняно 3 1990 роком;

г) туберкульоз вважатиметься викоріненим (знищеним), якщо показник поширеності туберкульозу складатиме менше 1 випадку на 1 мільйон населення на рік (ці цілі ВООЗ ставить до 2050 року).

Це бажання, на наш погляд, втрачає реальність через невпинне зростання епідемії ВІЛ/СНІДу та хіміорезистентного туберкульозу. Це два основних гальма, які заважають взяти епідемію туберкульозу під контроль. 